\title{
Tomato root transcriptome response to a nitrogen-enriched soil patch
}

\author{
Daniel R Ruzicka1', Felipe H Barrios-Masias², Natasha T Hausmann², Louise E Jackson² and Daniel P Schachtman*1
}

\begin{abstract}
Background: Nitrogen (N), the primary limiting factor for plant growth and yield in agriculture, has a patchy distribution in soils due to fertilizer application or decomposing organic matter. Studies in solution culture oversimplify the complex soil environment where microbial competition and spatial and temporal heterogeneity challenge roots' ability to acquire adequate amounts of nutrients required for plant growth. In this study, various ammonium treatments (as ${ }^{15} \mathrm{~N}$ ) were applied to a discrete volume of soil containing tomato (Solanum lycopersicum) roots to simulate encounters with a localized enriched patch of soil. Transcriptome analysis was used to identify genes differentially expressed in roots 53 hrs after treatment.
\end{abstract}

Results: The ammonium treatments resulted in significantly higher concentrations of both ammonium and nitrate in the patch soil. The plant roots and shoots exhibited increased levels of ${ }^{15} \mathrm{~N}$ over time, indicating a sustained response to the enriched environment. Root transcriptome analysis identified 585 genes differentially regulated 53 hrs after the treatments. Nitrogen metabolism and cell growth genes were induced by the high ammonium ( $65 \mathrm{\mu g} \mathrm{NH}_{4}{ }^{+} \mathrm{N} \mathrm{g}^{-1}$ soil), while stress response genes were repressed. The complex regulation of specific transporters following the ammonium pulse reflects a simultaneous and synergistic response to rapidly changing concentrations of both forms of inorganic $\mathrm{N}$ in the soil patch. Transcriptional analysis of the phosphate transporters demonstrates cross-talk between $\mathrm{N}$ and phosphate uptake pathways and suggests that roots increase phosphate uptake via the arbuscular mycorrhizal symbiosis in response to N.

Conclusion: This work enhances our understanding of root function by providing a snapshot of the response of the tomato root transcriptome to a pulse of ammonium in a complex soil environment. This response includes an important role for the mycorrhizal symbiosis in the utilization of an N patch.

\section{Background}

Nitrogen $(\mathrm{N})$ is often a primary limiting factor for plant growth and yield in agriculture. Applications of $\mathrm{N}$ in conventional agriculture include fertilizer banding to the side of the plants, broadcasting on the surface of soil, and anhydrous ammonia injections. These $\mathrm{N}$ application methods as well as localized microbial turnover of organic $\mathrm{N}$ can result in spatial and temporal heterogeneity (patchiness) of soil $\mathrm{N}$ resulting in non-uniform availability to plant roots. Furthermore, the rapid immobilization and nitrification of $\mathrm{N}$ additions by soil

\footnotetext{
* Correspondence: dschachtman@danforthcenter.org

1 Donald Danforth Plant Science Center, 975 N Warson Rd., St. Louis MO 63132 USA

Full list of author information is available at the end of the article
}

microbes can quickly alter $\mathrm{N}$ availability to the root [1-3]. Roots respond to localized nutrient patches by up-regulating ion transporters and by the proliferation of new roots into the patch to capture the additional $\mathrm{N}$ [4-6]. Mycorrhizal fungi provide plants with an additional mechanism to explore the soil and capture nutrients from enriched regions, increasing nutrient uptake potential $[7,8]$.

Plant roots predominantly acquire $\mathrm{N}$ from the rhizosphere as inorganic ammonium $\left(\mathrm{NH}_{4}^{+}\right)$or nitrate $\left(\mathrm{NO}_{3}^{-}\right)$, and subsequently assimilate intracellular $\mathrm{NH}_{4}{ }^{+}$into amino acids $[9,10]$. Roots sense and respond to changes in internal and external $\mathrm{N}$ status, which includes the regulation of gene expression, metabolism, and further $\mathrm{N}$ uptake and assimilation [11,12]. High and low affinity $\mathrm{N}$ 
transport systems in roots allow plants to maximize uptake depending on soil $\mathrm{N}$ availability. High affinity transport systems are induced or activated under conditions where soil $\mathrm{N}$ availability is reduced $(1 \mu \mathrm{M}$ to 0.5 $\mathrm{mM}$ ), while low affinity transport systems (active above $\sim 0.5 \mathrm{mM} \mathrm{N}$ ) may be constitutively expressed and transport $\mathrm{N}$ into the plant when soil $\mathrm{N}$ concentrations are high [13]. Members of the $\mathrm{NH}_{4}{ }^{+}$transporter (AMT) gene family [14] transport $\mathrm{NH}_{4}{ }^{+}$across the plasma membrane of root epidermal cells where it may be locally assimilated [15]. Intracellular $\mathrm{NH}_{4}{ }^{+}$is assimilated into glutamine and glutamate via the N-regulated glutamine synthetase (GS) and glutamate synthase (GOGAT) enzymes [16]. The $\mathrm{NO}_{3}{ }^{-}$transporters (NRT) are also encoded by a large gene family [17]. The $\mathrm{NO}_{3}{ }^{-}$taken up by roots can be translocated to the shoot or reduced in roots to nitrite $\left(\mathrm{NO}_{2}{ }^{-}\right)$ and then $\mathrm{NH}_{4}{ }^{+}$via $\mathrm{N}$-regulated $\mathrm{NO}_{3}{ }^{-}$reductase and $\mathrm{NO}_{2}{ }^{-}$ reductase $[13,16]$. Both AMTs and NRTs exhibit complex gene regulation patterns in response to various forms and concentrations of $\mathrm{N}$. These transporters are regulated by internal and external $\mathrm{N}$ and provide roots with a mechanism to mount a coordinated response that may serve to increase $\mathrm{N}$ acquisition and metabolism $[11,18,19]$.

Recent studies have moved beyond examining expression changes of single genes or gene families to studying global changes in plant gene regulation by nutrients [1922]. Microarray analyses of Arabidopsis and tomato roots subjected to increased $\mathrm{NO}_{3}$ - identified hundreds of differentially regulated genes whose functions included $\mathrm{N}$ metabolism, cell growth, and transcription [19,21]. However, most genomics studies on plant nutrient metabolism have utilized hydroponic-grown non-mycorrhizal plants, potentially limiting their translatability to our understanding of roots response in soil where nutrients are not distributed uniformly and inorganic $\mathrm{N}$ is being transformed. In this report we used molecular tools to study root response to the application of known concentrations of $\mathrm{NH}_{4}{ }^{+}$in a well defined region of the soil. Our aim was to characterize how roots respond to a nutrient patch in natural soils where complex ecological processes are occurring including mycorrhizal colonization and the microbial transformation of $\mathrm{NH}_{4}{ }^{+}$to $\mathrm{NO}_{3}$ - This approach is in contrast to previous studies [19-22] that have used hydroponics to study responses to $\mathrm{NH}_{4}{ }^{+}$or $\mathrm{NO}_{3}{ }^{-}$singly rather than a dynamic situation which is more relevant to agriculture or natural ecosystems where $\mathrm{NH}_{4}{ }^{+}$is rapidly transformed to $\mathrm{NO}_{3}-$. We report on ${ }^{15} \mathrm{~N}$ uptake and translocation and the coordinated changes in gene expression patterns in mycorrhizal roots following a localized pulse of $\mathrm{NH}_{4}{ }^{+}$as $\mathrm{NO}_{3}{ }^{-}$gradually became more available.

\section{Results}

\section{Soil $\mathrm{N}$, plant status, and plant $\mathrm{N}$ uptake}

Previous work showed that the field soil used for this study contained low concentrations of inorganic $\mathrm{N}$, high soil $\mathrm{N}$ mineralization potential, moderate mycorrhizal colonization of tomato roots, and very few changes in the soil food web after nutrient addition [8]. In order to create a nutrient patch and recover roots that were directly exposed to the treatment, pots were prepared with a soil root in-growth core (ring) buried $5 \mathrm{~cm}$ below the soil surface and subsequently referred to as the patch (Figure 1a). A pulse of ${ }^{15} \mathrm{NH}_{4}{ }^{+}$was injected into the soil patch to simulate the short-term effects of soil inorganic $\mathrm{N}$ spatial heterogeneity. The experimental design consisted of the addition of a high $\mathrm{NH}_{4}{ }^{+}$treatment $\left(65 \mu \mathrm{g}{ }^{15} \mathrm{NH}_{4}{ }^{+}-\mathrm{N} \mathrm{g}^{-1}\right.$ soil) 100-fold higher than ambient $\mathrm{NH}_{4}{ }^{+}$levels, a low $\mathrm{NH}_{4}{ }^{+}$treatment $\left(6.5 \mu \mathrm{g}{ }^{15} \mathrm{NH}_{4}{ }^{+}-\mathrm{N} \mathrm{g}^{-1}\right.$ soil) 10 -fold higher than ambient $\mathrm{NH}_{4}{ }^{+}$levels, and a water treatment to control for any potential mobilization of nutrients that occurs when soil moisture is increased.

The $\mathrm{NH}_{4}{ }^{+}$treatments increased the soil inorganic $\mathrm{N}$ concentrations in the patch soil, simulating heterogeneous soil patches. In the high $\mathrm{NH}_{4}{ }^{+}$treatment group, the highest soil $\mathrm{NH}_{4}{ }^{+}$concentration $\left(39.7 \mu \mathrm{g} \mathrm{NH}_{4}{ }^{+} \mathrm{N} \mathrm{g}^{-1}\right.$ dry soil) was measured at the time of the first sampling which was $5 \mathrm{hrs}$ after injection. At $53 \mathrm{hrs}$ after treatment it remained significantly higher than controls $(25.3 \mu \mathrm{g}$ $\mathrm{NH}_{4}{ }^{+}-\mathrm{N} \mathrm{g}^{-1}$ dry soil) (Fig 1b), and by 96 hrs, decreased to $3.5 \mu \mathrm{g} \mathrm{NH}_{4}{ }^{+} \mathrm{N} \mathrm{g}^{-1}$ dry soil due to microbial transformations and/or plant uptake of the added $\mathrm{NH}_{4}{ }^{+}$. In the high $\mathrm{NH}_{4}{ }^{+}$treatment rings, soil $\mathrm{NO}_{3}{ }^{-}$concentrations were above ambient levels within 29 hours, indicating nitrification of $\mathrm{NH}_{4}{ }^{+}$(Figure 1c). Patch soil $\mathrm{NO}_{3}{ }^{-}$concentrations increased over the first $53 \mathrm{hrs}$ after injection of the high $\mathrm{NH}_{4}{ }^{+}$treatment. In the low $\mathrm{NH}_{4}{ }^{+}$treatment, soil $\mathrm{NH}_{4}{ }^{+}$ and $\mathrm{NO}_{3}{ }^{-}$concentrations were similar to the water controls.

Over the course of the experiment, plant shoot growth was unaffected by treatment $(\mathrm{P}=0.78)$. Percent total $\mathrm{N}$ (mean \pm SE) in the shoots was $2.29 \% \pm 0.08$ at the time of treatment and unaffected by the $\mathrm{N}$ treatments $(\mathrm{P}=0.85)$. Percent phosphate $(\mathrm{P})$ (mean $\pm \mathrm{SE}$ ) in the shoots was $0.18 \% \pm 0.002$ and was unaffected by the $\mathrm{N}$ treatments. Roots were significantly colonized by arbuscular mycorrhizal fungi as measured by microscopic counting $(33.5 \%$ \pm 8.4 , mean $\pm \mathrm{SE}$ ) and fungal transcript analysis (data not shown).

To test whether the $\mathrm{NH}_{4}{ }^{+}$treatments resulted in measurable ${ }^{15} \mathrm{~N}$ uptake and translocation, atom percent ${ }^{15} \mathrm{~N}$ was assayed in roots and leaves (Figure 1d and 1e). 

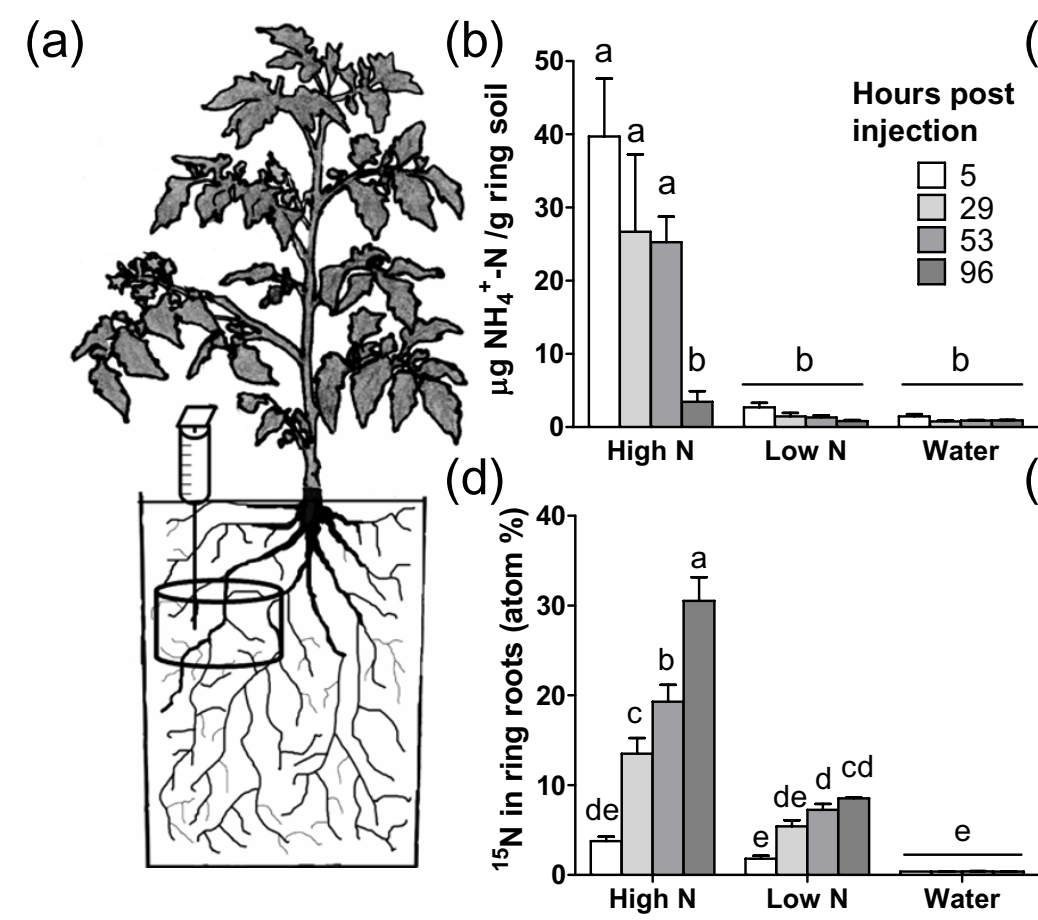

(c)

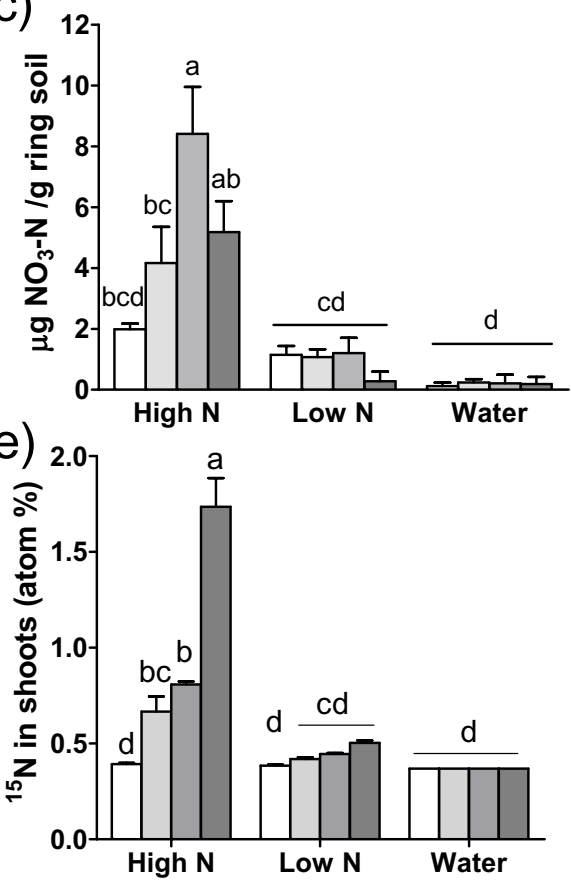

Figure 1 Ammonium treatments altered soil nitrogen dynamics and plant $\mathbf{N}$ uptake. (a) Diagram of pot-grown tomato plants where water, low

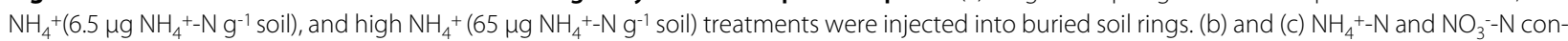
centrations per gram of patch soil in the three treatment groups at 5, 29, 53, and 96 hrs after injection. (d) and (e) atom percent $15 \mathrm{~N}$ in roots and shoots $5,29,53$, and 96 hrs after injection of the three treatment groups with ${ }^{15} \mathrm{~N}$ labeled $\mathrm{NH}_{4}{ }^{+}$fertilizer. Data represent the mean \pm SEM of 3 biological replicates. Within each graph, means followed by different letters are significantly different from one another at P $<0.05$ (two-way ANOVA with TukeyKramer HSD test).

Within 29 hrs, patch roots and leaves from high $\mathrm{NH}_{4}{ }^{+}$ plants contained increased amounts of ${ }^{15} \mathrm{~N}$ compared to naturally occurring ${ }^{15} \mathrm{~N}$ levels in the water control. The amount of ${ }^{15} \mathrm{~N}$ in these tissues continued to increase over time. In the patch roots from the low $\mathrm{NH}_{4}{ }^{+}$treatment, atom $\%{ }^{15} \mathrm{~N}$ was not higher compared to the water controls until $53 \mathrm{hrs}$ after injection, and there was no significant enrichment detected in leaves of the low $\mathrm{NH}_{4}{ }^{+}$ treatments at any time point. There were significantly higher concentrations of ${ }^{15} \mathrm{~N}$ in the high $\mathrm{NH}_{4}{ }^{+}$treatment roots and leaves compared to the low $\mathrm{NH}_{4}{ }^{+}$treatment samples at multiple time points, further confirming a physiological difference between these treatments.

\section{Microarray analysis of patch root transcription}

Affymetrix Tomato GeneChips were used to analyze the root transcriptome at $53 \mathrm{hrs}$ post-treatment; when ${ }^{15} \mathrm{~N}$ enrichment levels were detected in roots from both high and low $\mathrm{NH}_{4}{ }^{+}$treatment groups. Array analysis detected expression of 5822 of the 9524 transcripts contained on the tomato genechip. Statistical analyses identified 585 genes that were significantly altered in expression among the three treatment groups (Additional file 1). The high
$\mathrm{NH}_{4}{ }^{+}$treatment resulted in a much larger transcriptome response than the low $\mathrm{NH}_{4}{ }^{+}$treatment, with 535 genes differentially expressed between the high $\mathrm{NH}_{4}{ }^{+}$treatment and water control, compared to 89 genes with different expression levels between low $\mathrm{NH}_{4}{ }^{+}$treatment and water control (Figure 2a). While there were many differences between the regulated genes under high or low $\mathrm{NH}_{4}{ }^{+}$vs. water control treatments, 39 genes were identified as differentially regulated in both comparison groups, and all 39 were similarly regulated by the high and low $\mathrm{NH}_{4}{ }^{+}$ treatments compared to water (Figure 2a and Additional file 2).

We annotated and categorized nearly $80 \%$ of the 585 differentially regulated genes into putative functional classes. The $\mathrm{NH}_{4}{ }^{+}$treatments resulted in the differential regulation of genes in a wide range of functional categories (Figure 2b). In every functional category, the high $\mathrm{NH}_{4}{ }^{+}$vs. water comparison contained a significantly higher number of genes compared to the low $\mathrm{NH}_{4}{ }^{+}$vs. water comparison, further indicating that the high $\mathrm{NH}_{4}{ }^{+}$ treatment resulted in a larger scale transcriptional response. Fisher's exact test was used to determine 


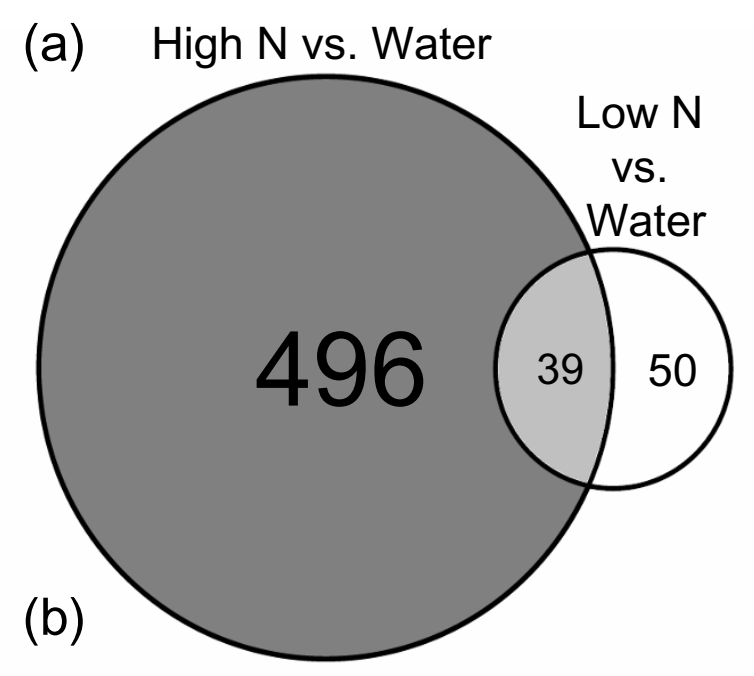

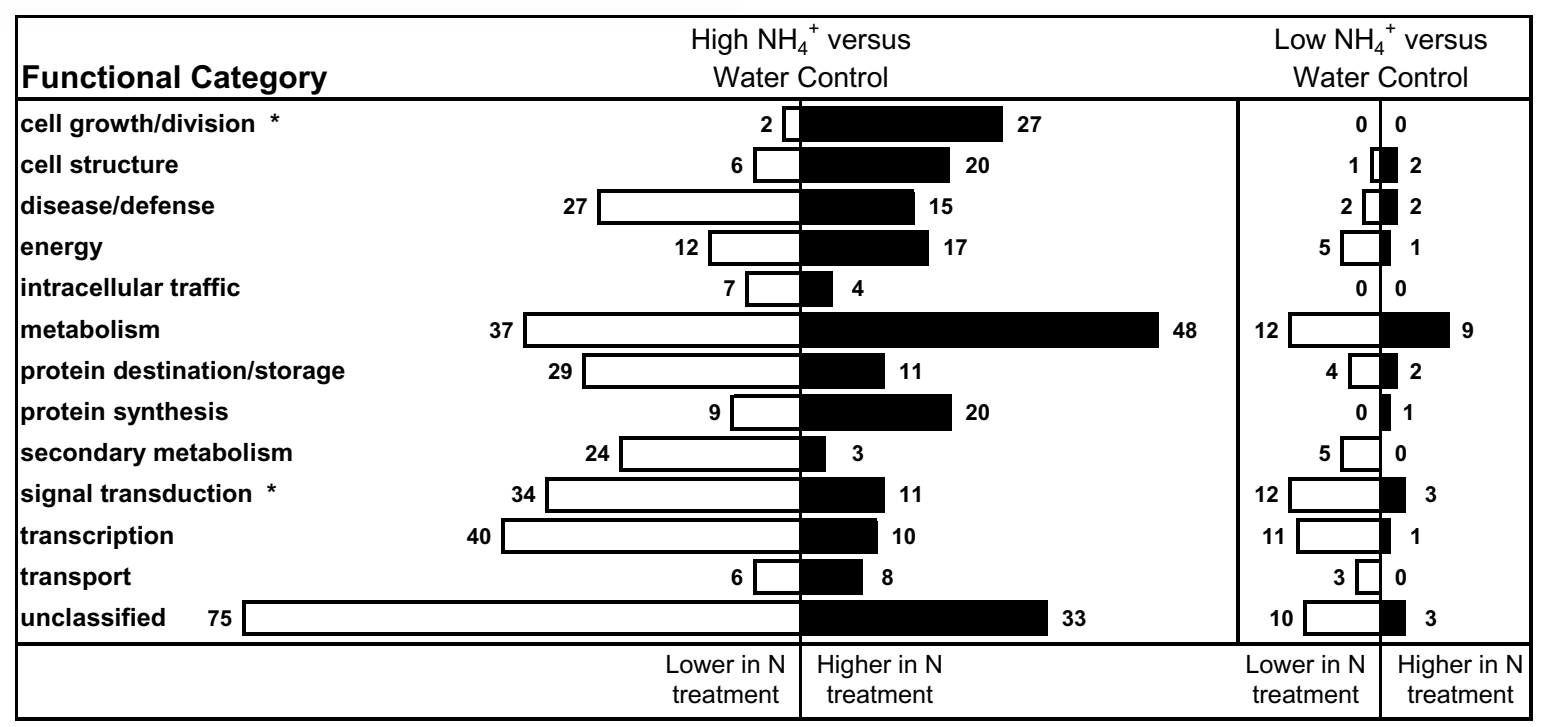

Figure 2 Classification of nitrogen treatment-regulated genes into defined functional categories. (a) Venn diagram displaying the number of genes identified in either or both the high $\mathrm{NH}_{4}{ }^{+}$vs. water and low $\mathrm{NH}_{4}{ }^{+} \mathrm{v}$ s. water comparisons. (b) Affymetrix probeset sequences were matched to publicly available Genbank accession identifications and categorized according to tomato or Arabidopsis orthologue gene annotations. Differential expression was analyzed at 53h post treatment. Black bars represent the number of genes more highly expressed in the $\mathrm{NH}_{4}{ }^{+}$treatment compared to the water treatment, and white bars represent the number more highly expressed in the water treatment compared to the $\mathrm{NH}_{4}{ }^{+}$treatment. Asterisks indicate a significant difference in the proportion of genes in those functional categories between the high $\mathrm{NH}_{4}{ }^{+} \mathrm{Vs}$. water and low $\mathrm{NH}_{4}{ }^{+} \mathrm{vs}$. water comparisons.

whether the gene lists from the [high $\mathrm{NH}_{4}{ }^{+}$vs. water] or [low $\mathrm{NH}_{4}{ }^{+}$vs. water] comparisons were enriched for different functional categories compared to one another, indicating a unique type of response to the two $\mathrm{NH}_{4}{ }^{+}$ treatments. Significantly more cell growth and division genes were identified in the high $\mathrm{NH}_{4}{ }^{+}$vs. water comparison (29 out of 535, 5.4\%) than the low $\mathrm{NH}_{4}{ }^{+}$vs. water comparison ( 0 out of $89,0 \%)(\mathrm{P}=0.0245)$. Conversely, significantly more signal transduction genes were identified in the low $\mathrm{NH}_{4}{ }^{+}$vs. water comparison (15 out of 89,
16.9\%) than the high $\mathrm{NH}_{4}{ }^{+}$vs. water comparison (45 out of $535,8.4 \%)(\mathrm{P}=0.0187)$.

A significant proportion (39 out of $89,43.8 \%$ ) of the genes in the low $\mathrm{NH}_{4}{ }^{+}$vs. water comparison were similarly regulated in the high $\mathrm{NH}_{4}{ }^{+}$vs. water comparison (Additional file 2), and included $\mathrm{N}$ assimilation and metabolism genes such as glutamine synthetase and tryptophan synthase. Eight of the remaining 50 (16\%) genes uniquely identified only in the low $\mathrm{NH}_{4}{ }^{+}$vs. water comparison function in sugar metabolism including glucosyl 
hydrolase, trehalose 6-phosphate synthase, low affinity sucrose transporter SUT4, isocitrate lyase, and glucose 6phosphate translocator.

\section{Identification of genes regulated among the $\mathrm{N}$ treatments}

Multiple genes in the $\mathrm{N}$ transporters, $\mathrm{N}$ metabolism, and amino acid metabolism subcategories were highly responsive to the $\mathrm{NH}_{4}{ }^{+}$treatments. The high $\mathrm{NH}_{4}{ }^{+}$treatment resulted in the increased expression level of $\mathrm{N}$ transporter, assimilation, and metabolism genes in roots including $\mathrm{NH}_{4}{ }^{+}$transporter $A M T 2, \mathrm{NO}_{3}{ }^{-}$transporter NRT2.1, nitrite reductase Nii2, glutamine synthetases GS (chloroplastic) and GTS1 (cytosolic), and NADH-dependant glutamate synthase GLT1 (GOGAT) (Table 1). Additional genes including peptide transporter 1 (LeOPT1), $\mathrm{NH}_{4}{ }^{+}$transporter 1 (AMT1), and nitrilase (NIT4) exhibited lower expression levels in the high $\mathrm{NH}_{4}{ }^{+}$treatment roots compared to water control samples. The nitrate transporters NRT2.3 and NRT3.2 were found on the array but were not differentially regulated among the treatment groups. Multiple amino acid metabolism genes were regulated by the $\mathrm{N}$ treatments including higher expression levels of two aspartate aminotransferases, an alanine aminotransferase, and a tryptophan synthase (Table 1). Lower expression levels of chorismate synthase 2 and alpha-aminoadipic semialdehyde synthase were detected (Table 1). A tomato MADS-Box transcription factor similar to the Arabidopsis N-starvation response transcription factor ANR1 was expressed 3.26-fold higher in the water control treatment compared to high $\mathrm{NH}_{4}{ }^{+}$samples (Table 1).

We used qRT-PCR to quantify the expression of key N metabolism genes to confirm the accuracy of the array results. The qRT-PCR results largely agreed with both the direction and magnitude of expression levels across the three treatments, including three genes that were not significantly different by array or qRT-PCR (glutamate dehydrogenase GDH1, ferrodoxin-dependant glutamate synthase GLS1.2 (GOGAT), and asparagine synthetase ASN1) (Figure 3).

Microarrays identified genes that were differentially regulated among the $\mathrm{NH}_{4}{ }^{+}$treatments from other functional categories including cell growth/division, cell wall biosynthesis, and stress/defense response, and sulfur metabolism (Figure 2b, Tables 2, 3, and 4, and Additional file 1). In the cell growth and division category, there were significantly more genes induced by the high $\mathrm{NH}_{4}{ }^{+}$treatment vs. water control than repressed by the high $\mathrm{NH}_{4}{ }^{+}$ treatment (27 out of 29 cell growth and division genes induced by high $\mathrm{NH}_{4}+, \mathrm{P}<0.001$ ) (Table 2). This category of genes included multiple cyclins, histones, and other growth factors. A similar pattern was observed for cell wall biosynthesis genes encoding multiple pectinest- erases, expansins, endo-xyloglucan transferases, and cellulose synthase (18 out of 20 induced by high $\mathrm{NH}_{4}{ }^{+}, \mathrm{P}<$ 0.001) (Table 3).

The $\mathrm{NH}_{4}{ }^{+}$treatments caused various transcriptional responses in multiple stress and defense-response genes, and genes in this functional category were some of the most differentially regulated genes of the experiment (Table 4). Genes in certain stress and defense response subcategories exhibited similar transcriptional responses including glutathione metabolism genes (6 out of 7 higher expression in water samples), pathogen response factors (5 out of 6 higher expression in water samples), and heat shock proteins ( 6 out of 7 higher expression in high $\mathrm{NH}_{4}{ }^{+}$ samples).

\section{Phosphate transporters}

The patch roots in this study were colonized by arbuscular mycorrhizal (AM) fungi therefore we examined the transcriptome data to determine whether the $\mathrm{NH}_{4}{ }^{+}$treatments might affect known symbiosis processes including the transcriptional regulation of the phosphate transporters (PTs). The tomato PTs group into mycorrhiza-specific, mycorrhiza-induced, and nonspecific root expression patterns, and are indicators of Pi status and the mycorrhizal symbiosis [23-26]. The Affymetrix tomato genechip only includes nonspecific phosphate transporter 1 (PT1), and it was 1.6-fold higher in the water samples compared to the low $\mathrm{N}$ treatment $(\mathrm{P}=$ 0.004). To test whether the $\mathrm{NH}_{4}{ }^{+}$treatments resulted in the differential regulation of the other PT family genes, we assayed the expression of the tomato phosphate transporters PT1, 2, 3, 4, and 5 with qRT-PCR (Figure 4). Expression of nonspecific PT1 and PT2 were 1.9- and 3.1fold higher in the water samples compared to the low $\mathrm{N}$ treatment samples $(\mathrm{P}=0.003$ and 0.046 , respectively). Mycorrhiza-induced PT3 and mycorrhiza-specific PT4 expression levels were 5.0- and 5.7- fold higher, respectively, in the low $\mathrm{NH}_{4}+$ treatment group compared to the water control samples $(\mathrm{P}=0.014$ and 0.045 , respectively). Mycorrhiza-induced PT5 expression was not different among the treatments. The expression level of the phosphate starvation-induced tomato gene TPSI1 was 7.5-fold higher in the water samples compared to the low $\mathrm{NH}_{4}{ }^{+}$ treatment $(\mathrm{P}=0.019)$. Similar trends were found for the high $\mathrm{NH}_{4}{ }^{+}$treatments compared to water controls. We analyzed shoot Pi levels to test whether the alterations in $P T$ gene expression correlated with or resulted in changes in shoot total Pi levels, but they not significantly different across the treatments.

\section{Discussion}

Previous studies have reported the transcriptional regulation of genes in diverse functional groups including 
Table 1: Differentially regulated nitrogen assimilation and metabolism genes.

\begin{tabular}{|c|c|c|c|c|c|}
\hline Probe Set ID & $\begin{array}{l}\text { Putative } \\
\text { Annotation }\end{array}$ & $\begin{array}{c}\text { Fold Change } \\
\text { (High N vs. } \\
\text { water) }\end{array}$ & P-value & $\begin{array}{c}\text { Fold Change } \\
\text { (Low N vs. water) }\end{array}$ & P-value \\
\hline Les.224.1.S1_at & $\begin{array}{l}\text { glutamine } \\
\text { synthetase }\end{array}$ & 16.69 & 0.002 & 6.31 & 0.024 \\
\hline Les.2360.1.S1_at & nitrite reductase & 4.25 & 0.044 & 1.39 & 0.364 \\
\hline Les.3640.1.S1_at & $\begin{array}{l}\text { ammonium } \\
\text { transporter }\end{array}$ & 4.07 & 0.045 & 1.24 & 0.638 \\
\hline Les.2884.1.S1_at & $\begin{array}{l}\text { glutamine } \\
\text { synthetase }\end{array}$ & 3.23 & 0.044 & 1.39 & 0.365 \\
\hline Les.28.2.S1_a_at & $\begin{array}{l}\text { nitrate } \\
\text { transporter } 2.1\end{array}$ & 2.61 & 0.082 & 1.42 & 0.402 \\
\hline Les.987.1.A1_at & $\begin{array}{l}\text { aspartate } \\
\text { aminotransferase }\end{array}$ & 2.29 & 0.050 & -1.02 & 0.943 \\
\hline Les.987.3.S1_at & $\begin{array}{l}\text { aspartate } \\
\text { aminotransferase }\end{array}$ & 2.18 & 0.044 & -1.34 & 0.216 \\
\hline Les.5163.1.S1_at & $\begin{array}{l}\text { dicarboxylate } \\
\text { transport }\end{array}$ & 1.85 & 0.075 & 1.99 & 0.105 \\
\hline Les.899.1.S1_at & $\begin{array}{l}\text { NADH-dependent } \\
\text { glutamate } \\
\text { synthase }\end{array}$ & 1.76 & 0.064 & -1.05 & 0.834 \\
\hline Les.3626.1.S1_at & $\begin{array}{l}\text { alanine } \\
\text { aminotransferase }\end{array}$ & 1.71 & 0.092 & 1.36 & 0.246 \\
\hline Les.2756.1.A1_at & $\begin{array}{l}\text { tryptophan } \\
\text { synthase-related }\end{array}$ & 1.53 & 0.095 & 2.01 & 0.078 \\
\hline Les.231.1.S1_at & $\begin{array}{l}\text { O- } \\
\text { acetyl(thiol)serine } \\
\text { lyase }\end{array}$ & 1.32 & 0.136 & 1.63 & 0.088 \\
\hline Les.3660.1.S1_at & $\begin{array}{l}\text { chorismate } \\
\text { synthase } 2\end{array}$ & -1.73 & 0.061 & -1.36 & 0.180 \\
\hline Les.299.1.S1_at & $\begin{array}{l}\text { peptide } \\
\text { transporter } 1\end{array}$ & -1.75 & 0.093 & -1.37 & 0.254 \\
\hline Les.797.1.S1_at & $\begin{array}{l}\text { ammonium } \\
\text { tranporter } 1\end{array}$ & -1.80 & 0.065 & -1.09 & 0.700 \\
\hline Les.3289.1.S1_at & $\begin{array}{l}\text { g-aminobutyrate } \\
\text { transaminase } \\
\text { subunit precursor }\end{array}$ & -1.84 & 0.053 & -1.76 & 0.105 \\
\hline
\end{tabular}


Table 1: Differentially regulated nitrogen assimilation and metabolism genes. (Continued)

\begin{tabular}{|c|c|c|c|c|c|}
\hline Les.7.1.S1_at & $\begin{array}{l}\text { homogentisate } \\
\text { 1,2-dioxygenase } \\
\text { HGO }\end{array}$ & -1.98 & 0.092 & -1.54 & 0.214 \\
\hline Les.1493.1.S1_at & nitrilase & -2.02 & 0.098 & -1.65 & 0.192 \\
\hline $\begin{array}{l}\text { LesAffx.3336.1.S1 } \\
\text { _at }\end{array}$ & $\begin{array}{l}\text { cystathionine } \\
\text { beta-synthase } \\
\text { domain protein }\end{array}$ & -2.15 & 0.108 & -3.60 & 0.078 \\
\hline Les.3071.1.S1_at & $\begin{array}{l}\text { alpha- } \\
\text { aminoadipic } \\
\text { semialdehyde } \\
\text { synthase }\end{array}$ & -2.27 & 0.067 & -2.35 & 0.105 \\
\hline Les.5024.1.S1_at & $\begin{array}{l}\text { ANR1-like MADS- } \\
\text { box transcription } \\
\text { factor }\end{array}$ & -3.26 & 0.067 & -2.28 & 0.156 \\
\hline
\end{tabular}

Probe Set ID; Affymetrix identifier for each microarray probeset. Putative Annotation; functional annotation based on tomato protein function or function of Arabidopsis orthologues identified with BLAST searches. Fold Change; linear fold changes (bold values significant at False Discovery Rate (FDR) adjusted P-value $<0.10$ ). High $\mathrm{N}=$ added $65 \mu \mathrm{g}^{15} \mathrm{NH}_{4}-\mathrm{N}$ per gram soil, low $\mathrm{N}=$ added $6.5 \mu \mathrm{g}{ }^{15} \mathrm{NH}_{4}-\mathrm{N}$ per gram soil. Probe Set IDs Les.987.1.A1_at and Les.987.3.S1_at represent the same genes.

metabolism, energy, cell growth, and transcription/translation in response to $\mathrm{N}$ nutrition as $\mathrm{NO}_{3}{ }^{-}$or $\mathrm{NH}_{4}{ }^{+}$[19-22]. However, these have utilized hydroponics systems that do not necessarily reflect the rhizosphere environment encountered by plant roots in agricultural and natural ecosystems. Roots grown in solution culture systems do not compete with soil microbes for nutrients, and the concentrations of nutrients in solution are more uniform both spatially and temporally. Fertilizer application and soil processes in conventional and organic farming result in the formation of heterogeneous soil nutrient patches [4], and plant utilization of $\mathrm{N}$ patches depends on roots rapidly sensing and response to the local enrichment of nutrients where they are in competition with soil microbial $\mathrm{N}$ assimilation and nitrification, leaching, and denitrification $[2,3,27,28]$.

To better understand plant root response to a localized and dynamic inorganic $\mathrm{N}$ soil patch, we utilized an experimental design that simulated a more realistic patch environment. The buried ring created the spatial attributes of an $\mathrm{N}$ patch by ensuring that harvested roots were localized to the $\mathrm{NH}_{4}{ }^{+}$treatment patch. Measurements of soil $\mathrm{NH}_{4}{ }^{+}$and $\mathrm{NO}_{3}{ }^{-}$levels confirmed dynamic soil transformations of available $\mathrm{N}$ by $53 \mathrm{hrs}$ when we sampled the roots for microarray analysis. After $96 \mathrm{hrs}$, we observed a trend of decreasing $\mathrm{NH}_{4}{ }^{+}$and $\mathrm{NO}_{3}{ }^{-}$soil levels, indicating plant and microbial uptake of both $\mathrm{NH}_{4}{ }^{+}$and $\mathrm{NO}_{3}{ }^{-}[1,9]$. Furthermore, estimates of the \% recovery of applied ${ }^{15} \mathrm{~N}$ in shoots from high and low $\mathrm{NH}_{4}{ }^{+}$treatment groups after 96 hrs (22\% and 21\%, respectively) support the assertion that roots faced significant competition for $\mathrm{N}$ in the soil environment.

The rapid $\mathrm{N}$ uptake observed in this study demonstrates the ability of tomato roots to quickly capture fertilizer in soil patches $[29,30]$. The roots that encountered the high $\mathrm{NH}_{4}{ }^{+}$treatment took up and translocated significantly more ${ }^{15} \mathrm{~N}$ from the patch than the low $\mathrm{NH}_{4}{ }^{+}$treatment roots. This observation is in agreement with the larger transcriptional response to the high $\mathrm{NH}_{4}{ }^{+}$treatment including multiple nitrogen transport, assimilation, and metabolism genes. However, the relatively low \% recovery suggests that actual uptake and assimilation are only a small fraction of what was initially available despite the rapid root responses.

The genes coordinately regulated in both high and low treatments may represent a conserved physiological response to different ranges of $\mathrm{N}$ patch conditions. The co-regulated list of genes did not include the $\mathrm{NH}_{4}{ }^{+}$or $\mathrm{NO}_{3}{ }^{-}$transporters $A M T 1, A M T 2$, or NRT2.1 identified in the high $\mathrm{NH}_{4}{ }^{+}$vs. water control comparison. We speculate that roots in the high $\mathrm{NH}_{4}{ }^{+}$patch needed additional transporters to effectively capture the higher soil N levels, while constitutively expressed transporters were sufficient in the low $\mathrm{NH}_{4}{ }^{+}$patch. Of equal interest, however, is the set of 50 genes regulated by the low $\mathrm{NH}_{4}{ }^{+}$treatment 


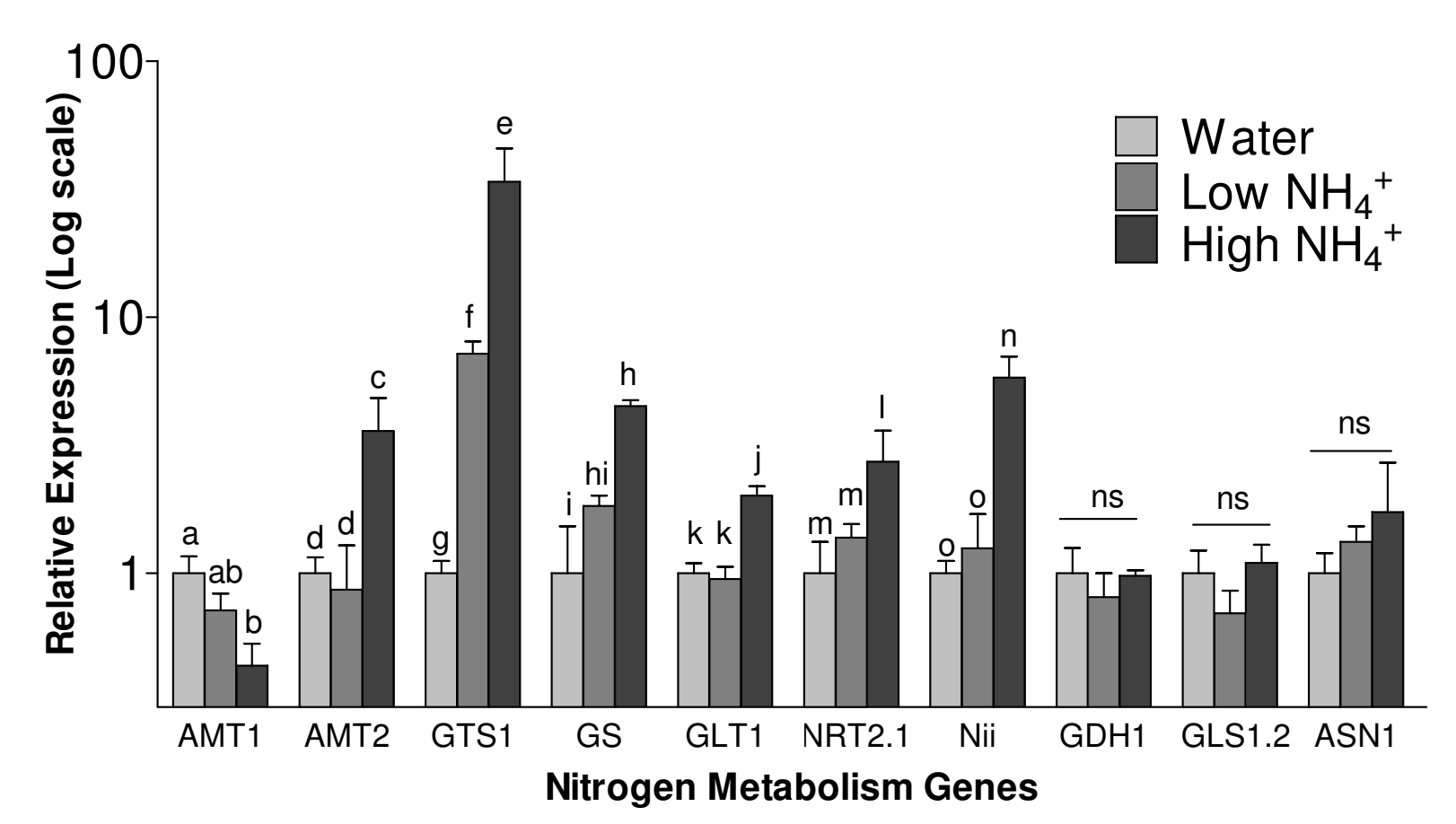

Figure 3 qRT-PCR analysis of key nitrogen metabolism genes. Expression levels of $\mathrm{NH}_{4}^{+}$transporters AMT1 and AMT2, glutamine synthetases GTS1 and GS, $\mathrm{NO}_{3}$ - transporter NRT2.1, nitrite reductase Nii, NADH-dependant glutamate synthase GLT1 (GOGAT), glutamate dehydrogenase GDH1, ferrodoxin-dependant glutamate synthase GLS1.2 (GOGAT), and asparagine synthetase ASN1 in patch roots harvested 53 hrs after high $\left(65 \mathrm{\mu g} \mathrm{NH}_{4}^{+{ }^{+}}\right.$ $\mathrm{N} \mathrm{g}^{-1}$ soil), low $\left(6.5 \mathrm{\mu g} \mathrm{NH}_{4}{ }^{+}-\mathrm{N} \mathrm{g}^{-1}\right.$ soil), or water control treatments. Relative quantity was calculated using the $\triangle \triangle C T$ method with actin (LeACT) as the reference control, and the water control group normalized to 1. For a given gene, means followed by different letters are significantly different from one another at $\mathrm{P}<0.05$ (one way ANOVA).

that were not similarly regulated by the high $\mathrm{NH}_{4}{ }^{+}$treatment. This group of genes included a significant number of sugar metabolism genes for which we have no clear explanation as to the functional significance for the change in regulation. One possibility is that sugar metabolism may have been required for the production of root exudates, which can increase plant growth promoting rhizobacteria, or stimulate $\mathrm{N}$ cycling by microbial populations in the rhizosphere [31]. While the total number of genes regulated by the two treatments suggests that the high $\mathrm{NH}_{4}{ }^{+}$treatment caused a larger response, the responses were in part unique, and may reflect different strategies to effectively utilize the $\mathrm{N}$ patch. Increased $\mathrm{N}$ availability stimulates highly regulated root development and growth in order to efficiently scavenge and assimilate the additional soil $\mathrm{N}[32,33]$. The induction of multiple histone gene family members such as histones $\mathrm{H} 4, \mathrm{H} 3$ and $\mathrm{H} 2 \mathrm{AX}$ in the high $\mathrm{NH}_{4}{ }^{+}$treatment suggests an increase in DNA replication $[34,35]$, while the increased expression of a mitotic spindle checkpoint gene, replicon protein $\mathrm{A}$, multiple cyclin genes, and a putative $\operatorname{cdc} 20$ suggest an increase in cell division processes $[36,37]$. Furthermore, the induction of cell wall genes including expansins, pectinesterases, and cellulose synthase suggests an increase in cell wall biosynthesis that would be required during root growth [38]. In Arabidopsis, multiple expansins and other cell wall modification enzymes were up-regulated by $\mathrm{NO}_{3}-3 \mathrm{hrs}$ post-treatment [20], and gene expression profiling of maize roots in early response to a $\mathrm{NO}_{3}$ - treatment identified multiple genes involved in cell growth and lateral root elongation including alphaexpansin, kinesin, and cellulose synthase [39]. These experiments imply that similar $\mathrm{N}$ developmental response mechanisms are conserved across maize, Arabidopsis, and tomato roots, and that the root response to an $\mathrm{N}$ nutrient patch includes coordinated root growth.

In this study, diverse stress response genes encoding heat-shock proteins, glutathione transferases, thioredoxin, pathogenesis-related proteins, and dehydration/ desiccation responsive proteins were found to be differentially expressed among the $\mathrm{NH}_{4}{ }^{+}$treatment groups. Limiting nutrient conditions cause various stress-related responses including the up-regulation of reactive oxygen species metabolism [40]. Chronic $\mathrm{N}$ stress induces a range of plant stress responses which include the transcriptional regulation of numerous stress responsive 
Table 2: Differentially regulated cell growth and division genes.

\begin{tabular}{|c|c|c|c|}
\hline Probe Set ID & Putative Annotation & $\begin{array}{c}\text { Fold Change } \\
\text { (High N vs. water) }\end{array}$ & P-value \\
\hline Les.5082.1.S1_at & cdc20 cell cycle regulator & 3.46 & 0.044 \\
\hline Les.2170.1.A1_at & cyclin & 2.89 & 0.062 \\
\hline Les.5789.1.S1_at & histone 3 & 2.74 & 0.045 \\
\hline Les.103.1.S1_at & cyclin A1 & 2.65 & 0.044 \\
\hline Les.3009.3.A1_at & histone HTA12 & 2.52 & 0.053 \\
\hline Les.3713.1.S1_at & $\begin{array}{l}\text { B2-type cyclin dependent } \\
\text { kinase }\end{array}$ & 2.48 & 0.044 \\
\hline Les.677.1.S1_at & histone $\mathrm{H} 2 \mathrm{AX}$ & 2.33 & 0.053 \\
\hline Les.677.2.A1_at & histone $\mathrm{H} 2 \mathrm{AX}$ & 2.31 & 0.061 \\
\hline Les.5740.1.S1_at & replicon protein $A$ & 2.28 & 0.044 \\
\hline LesAffx.66157.1.S1_at & mitotic arrest deficient-like & 2.21 & 0.068 \\
\hline LesAffx.19390.1.S1_at & cyclin & 2.16 & 0.044 \\
\hline Les.3209.1.S1_at & $\begin{array}{l}\text { histone } \mathrm{H} 4 \text { replacement } \\
\text { isoform }\end{array}$ & 2.11 & 0.044 \\
\hline Les.3090.1.S1_at & histone $\mathrm{H} 3$ & 2.08 & 0.044 \\
\hline Les.3555.1.S1_at & histone H2B-2 & 2.00 & 0.044 \\
\hline Les.4603.1.S1_at & histone $\mathrm{H} 3$ & 1.96 & 0.044 \\
\hline Les.5283.1.S1_at & $\begin{array}{l}\text { minichromosome } \\
\text { maintenance protein }\end{array}$ & 1.83 & 0.084 \\
\hline Les.4439.1.S1_at & histone H3 & 1.80 & 0.053 \\
\hline Les.4978.1.S1_at & DNA-dependant ATPase & 1.77 & 0.091 \\
\hline Les.4442.1.S1_s_at & histone H2B-1 & 1.73 & 0.044 \\
\hline LesAffx.57438.1.S1_at & $\begin{array}{l}\text { nucleosome chromatin } \\
\text { assembly factor }\end{array}$ & 1.72 & 0.081 \\
\hline Les.3209.2.A1_at & $\begin{array}{l}\text { histone } \mathrm{H} 4 \text { replacement } \\
\text { isoform }\end{array}$ & 1.72 & 0.062 \\
\hline
\end{tabular}


Table 2: Differentially regulated cell growth and division genes. (Continued)

\begin{tabular}{|c|c|c|c|}
\hline Les.4831.1.S1_at & $\begin{array}{l}\text { nucleosome chromatin } \\
\text { assembly factor }\end{array}$ & 1.64 & 0.053 \\
\hline Les.4539.1.S1_a_at & histone $\mathrm{H} 4$ & 1.57 & 0.091 \\
\hline LesAffx.2226.2.A1_at & ribonucleotide reductase-like & 1.57 & 0.091 \\
\hline Les.4564.1.S1_at & $\begin{array}{l}\text { microtubule associated } \\
\text { protein }\end{array}$ & 1.54 & 0.088 \\
\hline Les.2989.1.S1_at & histone HTA7 & 1.51 & 0.044 \\
\hline Les.4539.2.S1_at & histone $\mathrm{H} 4$ & 1.50 & 0.091 \\
\hline Les.3009.2.S1_at & histone HTA12 & 1.48 & 0.066 \\
\hline Les.4940.1.S1_at & cyclin & -1.56 & 0.088 \\
\hline Les.3563.1.S1_at & ER auxin binding protein 1 & -1.74 & 0.082 \\
\hline \multicolumn{4}{|c|}{$\begin{array}{l}\text { Probe Set ID; Affymetrix identifier for each microarray probeset. Putative Annotation; functional annotation based on tomato } \\
\text { function or function of Arabidopsis orthologues identified with BLAST searches. Fold Change; linear fold changes (bold values } \\
\text { False Discovery Rate (FDR) adjusted P-value < 0.10). Probe Set IDs representing the same genes include (Les.3009.3.A1_at and } \\
\text { Les.3009.2.S1_at), (Les.677.1.S1_at and Les.677.2.A1_at), (Les.3209.1.S1_at and Les.3209.2.A1_at) and (Les.4539.1.S1_a_at and } \\
\text { Les.4539.2.S1_at). }\end{array}$} \\
\hline
\end{tabular}

genes. In Arabidopsis $~ 35 \%$ of the genes upregulated by a severe chronic $\mathrm{N}$ limitation stress were classified as response to abiotic stimulus, general stress, or oxidative stress [41]. Studies of $\mathrm{N}$ effects on the expression of stress response genes in rice also indicate that $\mathrm{N}$ limiting conditions cause the differential regulation of biotic and abiotic stress genes [42]. From their studies, Lian et al. postulate that this could be due to the perception of $\mathrm{N}$ limitation as a biotic or abiotic stress that requires a conserved set of regulated genes that play protective roles [42]. Our results suggest that the conditions in the water control samples may have initiated a stress response in roots due to an $\mathrm{N}$ limitation, and that the high and low $\mathrm{NH}_{4}{ }^{+}$treatments alleviated this coordinated stress response.

The complex regulation of specific $\mathrm{NH}_{4}{ }^{+}$and $\mathrm{NO}_{3}{ }^{-}$ transporters following the $\mathrm{NH}_{4}{ }^{+}$pulse may reflect a simultaneous and synergistic response to both $\mathrm{NH}_{4}{ }^{+}$and $\mathrm{NO}_{3}{ }^{-}$in the soil patch. Both Arabidopsis AtAMT1.1 and tomato LeAMT1 exhibit increased transcript levels during $\mathrm{N}$ deprivation and are repressed by $\mathrm{NO}_{3}{ }^{-}$and $\mathrm{NH}_{4}{ }^{+}$ [43-45]. The higher expression of LeAMT1 under control conditions and its repression by high $\mathrm{NH}_{4}{ }^{+}$in the present study further support the idea that LeAMT1 is a high affinity ammonium transporter whose expression is regu- lated by $\mathrm{N}$-limiting conditions to increase $\mathrm{NH}_{4}{ }^{+}$uptake. In two hydroponics studies, LeAMT2 was induced by increased concentrations of $\mathrm{NH}_{4}{ }^{+}$over the course of 24 hrs but repressed by increased concentrations of $\mathrm{NO}_{3}{ }^{-}$ after 24 hrs $[19,44]$. The higher expression of LeAMT2 in response to the soil $\mathrm{N}$ patch $53 \mathrm{hrs}$ after treatment in this current study suggests that the positive effects of $\mathrm{NH}_{4}^{+}$ may be stronger than the long-term repressive effects of $\mathrm{NO}_{3}{ }^{-}$exposure. Arabidopsis, barley and tomato $\mathrm{NO}_{3}{ }^{-}$ transporters AtNRT2.1, HvNRT2, and LeNRT2.1 were induced by $\mathrm{NO}_{3}{ }^{-}$in hydroponic culture, and $\mathrm{NH}_{4}{ }^{+}$ repressed $H v N R T 2$ expression [13,19]. We report that LeNRT2.1 was induced in the high $\mathrm{NH}_{4}{ }^{+}$treatment where we measured increased $\mathrm{NO}_{3}-$ concentrations. The increased $\mathrm{NO}_{3}$ - in the patch may have induced LeNRT2.1, although the effects of $\mathrm{NH}_{4}{ }^{+}$alone in the absence of $\mathrm{NO}_{3}{ }^{-}$ on LeNRT2.1 remain to be tested. The complex regulation of the $\mathrm{NH}_{4}{ }^{+}$and $\mathrm{NO}_{3}{ }^{-}$transporters in this study indicate that tomato roots are able to quickly sense and respond to changing concentrations of $\mathrm{NH}_{4}{ }^{+}$and $\mathrm{NO}_{3}{ }^{-}$ simultaneously in a localized $\mathrm{N}$ patch, enhancing $\mathrm{N}$ uptake and utilization. Moreover, growth is known to increase with co-provision of $\mathrm{NH}_{4}{ }^{+}$and $\mathrm{NO}_{3}{ }^{-}$[22]. Recent 
Table 3: Differentially regulated cell wall metabolism genes.

\begin{tabular}{|c|c|c|c|c|c|}
\hline Probe Set ID & $\begin{array}{l}\text { Putative } \\
\text { Annotation }\end{array}$ & $\begin{array}{c}\text { Fold Change } \\
\text { (High N vs. } \\
\text { water) }\end{array}$ & P-value & $\begin{array}{c}\text { Fold Change } \\
\text { (Low N vs. } \\
\text { water) }\end{array}$ & P-value \\
\hline Les.3273.1.S1_at & $\begin{array}{l}\text { cell wall-plasma } \\
\text { membrane linker }\end{array}$ & 5.98 & 0.053 & 1.63 & 0.424 \\
\hline LesAffx.846.2.S1_at & pectinacetylesterase & 3.22 & 0.080 & -1.44 & 0.458 \\
\hline Les.3733.1.S1_at & expansin & 3.20 & 0.067 & 1.45 & 0.414 \\
\hline Les.3590.1.S1_at & $\begin{array}{l}\text { endo-xyloglucan } \\
\text { transferase }\end{array}$ & 3.12 & 0.081 & -1.33 & 0.565 \\
\hline LesAffx.4617.1.A1_at & pectinesterase & 3.10 & 0.063 & -1.41 & 0.417 \\
\hline Les.2316.1.S1_at & $\begin{array}{l}\text { cellulose synthase } \\
\text { isomer }\end{array}$ & 3.01 & 0.067 & 1.88 & 0.193 \\
\hline Les.2189.1.S1_at & pectinesterase & 2.51 & 0.070 & -1.07 & 0.868 \\
\hline Les.218.3.S1_at & pectinesterase & 2.07 & 0.094 & -1.14 & 0.710 \\
\hline Les.1604.1.A1_at & $\begin{array}{l}\text { cobra-like4 } \\
\text { phytocheletin } \\
\text { synthase }\end{array}$ & 1.91 & 0.096 & 1.51 & 0.219 \\
\hline Les.369.1.S1_at & expansin & 1.87 & 0.074 & 1.48 & 0.186 \\
\hline LesAffx.69659.1.S1_at & chitinase class IV & 1.82 & 0.063 & 1.65 & 0.127 \\
\hline Les.5233.1.S1_at & pectinesterase & 1.76 & 0.089 & 1.06 & 0.829 \\
\hline Les.218.1.S1_at & pectinesterase & 1.73 & 0.096 & 1.27 & 0.362 \\
\hline Les.3523.1.S1_at & polygalacturonase & 1.72 & 0.096 & 1.17 & 0.551 \\
\hline Les.4739.1.S1_at & $\begin{array}{l}\text { UDP-glucose:protein } \\
\text { transglucosylase }\end{array}$ & 1.70 & 0.048 & 1.28 & 0.196 \\
\hline Les.109.1.S1_at & beta-galactosidase & 1.61 & 0.065 & -1.02 & 0.944 \\
\hline Les.4707.1.S1_at & pectate lyase & 1.61 & 0.061 & 1.67 & 0.093 \\
\hline Les.2590.2.A1_at & $\begin{array}{l}\text { endo-xyloglucan } \\
\text { transferase A2-like }\end{array}$ & 1.40 & 0.085 & -1.05 & 0.743 \\
\hline
\end{tabular}


Table 3: Differentially regulated cell wall metabolism genes. (Continued)

\begin{tabular}{|c|c|c|c|c|c|}
\hline Les.4523.1.S1_at & $\begin{array}{l}\text { xyloglucan } \\
\text { endotransglucosylas } \\
\text { e-hydrolase }\end{array}$ & -2.53 & 0.079 & -1.58 & 0.265 \\
\hline Les.4652.1.S1_at & $\begin{array}{l}\text { esterase/lipase/ } \\
\text { thioesterase }\end{array}$ & -3.76 & 0.063 & -1.78 & 0.271 \\
\hline
\end{tabular}

studies have also reported root responses to soil glutamate that may have been available to patch roots [46]. This study highlights the ability of plant roots to simultaneously regulate multiple transporters for uptake of both forms of inorganic $\mathrm{N}$ as part of a plastic response strategy to quickly exploit the $\mathrm{N}$ pulse.

Numerous transcription factors were identified in the microarray study that may function as key regulators of a secondary response to the $\mathrm{N}$ enrichment. The tomato MADS-box transcription factor BT013126 shares 67\% amino acid sequence similarity with Arabidopsis ANR1 and is expressed 3.26-fold higher in the water control compared to the high $\mathrm{NH}_{4}{ }^{+}$treatment (Table 1). Arabidopsis ANR1 is a key regulator of the developmental response to $\mathrm{N}$ in roots and is induced by $\mathrm{N}$ starvation and repressed by $\mathrm{NO}_{3}-$ re-supply $[47,48]$. Prior to the $\mathrm{N}$ additions, the plants were most likely $\mathrm{N}$-limited as the shoot $\mathrm{N}$ concentration was below sufficiency levels (mean = $1.94 \%$ for water control) [49]. The expression pattern of this tomato ANR1-like gene in N patch roots corresponds to what was found in Arabidopsis, suggesting that its functional role to regulate root development in response to $\mathrm{N}$ is conserved across species and in diverse root environments.

Root responses to macronutrients N, P, potassium (K), and sulfur (S) are interconnected and may be due to the increased availability of one causing an imbalance in another. Previous studies have shown $\mathrm{N}$ addition to increase the expression level of $\mathrm{S}$ metabolism genes $[21,50]$, which could account for the changes in S metabolism genes reported here (Additional file 1). Alternatively, these genes may have been affected by sulfate in the $\mathrm{NH}_{4}{ }^{+}$treatment, although soil $\mathrm{S}$ concentrations were likely sufficient for the plant. Cross talk between $\mathrm{K}$ and $\mathrm{N}$ has also been shown where $\mathrm{K}$ deficiency alters the transcriptional and post-transcriptional activity of various $\mathrm{N}$ uptake, assimilation, and metabolism genes including three nitrate transporters [51,52]. Nitrogen and phosphate metabolism have been shown to be closely linked where $\mathrm{N}$ uptake results in coordinated P uptake [53,54]. However, in response to a $3 \mathrm{hr}$ nitrate pulse, phosphate transporter expression levels in hydroponics-grown Arabidopsis did not change [20]. In soils, mineral availability and acquisition is additionally affected by the mycorrhizal symbiosis, and previous work has linked the up-regulation of the fungal phosphate transporter GiPT to the presence of $\mathrm{N}$ [55]. In this current study, multiple phosphate transporters were regulated by the $\mathrm{NH}_{4}{ }^{+}$treatments, in contrast to the Arabidopsis findings [20]. We observed that mycorrhizal-induced PT3 and mycorrhizal-specific PT4 were more highly expressed when more $\mathrm{NH}_{4}{ }^{+}$was present in the soil. The PT3 and PT4 expression patterns suggest that arbuscular mycorrhizal Pi uptake may be enhanced by $\mathrm{NH}_{4}{ }^{+}$soil enrichment. Phosphate transporters PT1 and PT2 are found in both mycorrhizal and nonmycorrhizal root tissues, but are repressed in mycorrhizal roots [56-58]. The repression of PT1 and PT2 in the $\mathrm{NH}_{4}{ }^{+}$treatments in the present study further supports the conclusion that the $\mathrm{NH}_{4}{ }^{+}$treatments promoted the symbiotic Pi uptake pathway. In fact, Wang et al. reported that tomato PT2 was induced by $\mathrm{NO}_{3}{ }^{-}$in hydroponic-grown non-mycorrhizal roots [19], and thus it appears that $P T 2$ regulation in the current study was in response to up-regulation of the mycorrhizal Pi uptake pathway rather than soil $\mathrm{NO}_{3}$ - directly. We can speculate that the $\mathrm{NH}_{4}{ }^{+}$soil enrichment induced root growth in the nutrient patch, resulting in a localized $\mathrm{P}$ deficiency that promoted the mycorrhizal $\mathrm{Pi}$ uptake pathway. Importantly, the lower expression level of phosphate-starvation induced TPSI1 in the low and high $\mathrm{NH}_{4}{ }^{+}$treatment plants suggests that these roots were receiving more Pi than the water control samples [59], although this was not measured directly. This shift towards the mycorrhizal Pi uptake pathway may have resulted in increased Pi uptake, possibly as a mechanism to support $\mathrm{N}$-induced growth. Our results detail a novel and complex interaction between inorganic $\mathrm{N}$, the arbuscular mycorrhizal symbiosis, and the tomato phosphate transporter gene family, and suggest an important role for the symbiosis in the utilization of an $\mathrm{N}$ patch to increase $\mathrm{P}$ uptake and maintain $\mathrm{N}$-induced growth. 
Table 4: Differentially regulated stress and defense response genes.

\begin{tabular}{|c|c|c|c|c|c|}
\hline Probe Set ID & Putative Annotation & $\begin{array}{c}\text { Fold Change } \\
\text { (High N vs. } \\
\text { water) }\end{array}$ & P-value & $\begin{array}{c}\text { Fold Change } \\
\text { (Low N vs. } \\
\text { water) }\end{array}$ & P-value \\
\hline Les.2287.3.A1_at & $\begin{array}{l}\text { TAS14 peptide } \\
\text { dehydrin }\end{array}$ & -24.08 & 0.053 & -40.75 & 0.078 \\
\hline Les.5957.1.S1_at & $\begin{array}{l}\text { lactoylglutathione } \\
\text { lyase }\end{array}$ & -6.87 & 0.111 & -17.15 & 0.078 \\
\hline Les.293.1.S1_at & $\begin{array}{l}\text { hydroxyacylglutathio } \\
\text { ne hydrolase }\end{array}$ & -4.66 & 0.513 & -4.44 & 0.078 \\
\hline Les.23.1.S1_at & $\begin{array}{l}\text { glutathione S- } \\
\text { transferase }\end{array}$ & -4.54 & 0.569 & -3.07 & 0.078 \\
\hline Les.124.1.S1_at & $\begin{array}{l}\text { glutathione } \\
\text { transferase }\end{array}$ & -4.38 & 0.044 & -2.54 & 0.107 \\
\hline Les.5100.1.S1_at & $\begin{array}{l}\text { type I small heat shock } \\
\text { protein }\end{array}$ & -3.85 & 0.044 & -2.20 & 0.107 \\
\hline Les.4789.1.S1_at & $\begin{array}{l}\text { pathogenesis-related } \\
\text { protein }\end{array}$ & -3.47 & 0.062 & -2.12 & 0.115 \\
\hline Les.5341.1.S1_at & $\begin{array}{l}\text { pathogen responsive } \\
\text { alpha-dioxygenase } 2\end{array}$ & -2.76 & 0.098 & -1.85 & 0.131 \\
\hline Les.1645.1.A1_at & $\begin{array}{l}\text { pathogenesis-related } \\
\text { chitin-binding protein }\end{array}$ & -2.44 & 0.065 & -1.74 & 0.133 \\
\hline Les.4004.1.S1_a_at & $\begin{array}{l}\text { pathogenesis related } \\
\text { PR5-like protein }\end{array}$ & -2.26 & 0.070 & -1.59 & 0.143 \\
\hline Les.5098.1.S1_at & $\begin{array}{l}\text { early responsive to } \\
\text { dehydration 7-like }\end{array}$ & -2.20 & 0.064 & -1.42 & 0.152 \\
\hline LesAffx.47187.1.S1_at & $\begin{array}{l}\text { responsive to } \\
\text { dehydration 22-like }\end{array}$ & -2.12 & 0.058 & -1.34 & 0.165 \\
\hline Les.5103.1.S1_at & $\begin{array}{l}\text { pathogenesis-related } \\
\text { protein } 1 \text { like }\end{array}$ & -2.04 & 0.062 & -1.33 & 0.168 \\
\hline Les.3151.1.S1_at & $\begin{array}{l}\text { universal stress } \\
\text { protein }\end{array}$ & -1.99 & 0.084 & -1.33 & 0.168 \\
\hline Les.253.1.S1_at & $\begin{array}{l}\text { pathogenesis related } \\
\text { protein 1-like }\end{array}$ & -1.95 & 0.044 & -1.29 & 0.229 \\
\hline Les.4910.1.S1_at & $\begin{array}{l}\text { stress enhanced } \\
\text { protein 2-like }\end{array}$ & -1.93 & 0.085 & -1.26 & 0.232 \\
\hline
\end{tabular}


Table 4: Differentially regulated stress and defense response genes. (Continued)

\begin{tabular}{|c|c|c|c|c|c|}
\hline Les.1498.1.S1_at & $\begin{array}{l}\text { dehydration } \\
\text { responsive }\end{array}$ & -1.87 & 0.096 & -1.25 & 0.289 \\
\hline Les.208.1.S1_at & $\begin{array}{l}\text { glutathione S- } \\
\text { transferase }\end{array}$ & -1.72 & 0.062 & -1.22 & 0.340 \\
\hline Les.2657.1.S1_at & $\begin{array}{l}\text { rare cold inducible } \\
\text { protein-like }\end{array}$ & -1.70 & 0.095 & -1.20 & 0.377 \\
\hline Les.3194.1.S1_at & $\begin{array}{l}\text { universal stress } \\
\text { protein }\end{array}$ & -1.62 & 0.088 & -1.16 & 0.386 \\
\hline Les.5128.1.S1_at & $\begin{array}{l}\text { responsive to } \\
\text { dehydration 22-like }\end{array}$ & -1.61 & 0.044 & -1.14 & 0.454 \\
\hline Les.3276.3.S1_at & $\begin{array}{l}\text { monocysteinic } \\
\text { thioredoxin }\end{array}$ & -1.56 & 0.093 & -1.11 & 0.509 \\
\hline Les.252.1.S1_at & $\begin{array}{l}\text { wound-responsive } \\
\text { protein-related }\end{array}$ & -1.50 & 0.077 & -1.11 & 0.524 \\
\hline Les.54.1.S1_at & sulfiredoxin & 1.10 & 0.044 & -1.10 & 0.537 \\
\hline Les.248.2.A1_at & $\begin{array}{l}\text { glutathione S- } \\
\text { transferase }\end{array}$ & 1.14 & 0.095 & -1.08 & 0.796 \\
\hline Les.384.1.A1_at & $\begin{array}{l}\text { thaumatin-like } \\
\text { pathogenesis-related } \\
\text { PR-5 like protein }\end{array}$ & 1.42 & 0.070 & -1.07 & 0.850 \\
\hline Les.4307.1.S1_at & $\begin{array}{l}\text { early responsive to } \\
\text { dehydration 3-like }\end{array}$ & 1.47 & 0.053 & -1.05 & 0.870 \\
\hline Les.1394.1.A1_at & $\begin{array}{l}\text { heat shock factor } \\
\text { binding protein } 1\end{array}$ & 1.82 & 0.063 & 1.22 & 0.185 \\
\hline Les.3593.1.S1_at & heat shock protein & 2.13 & 0.044 & 1.45 & 0.204 \\
\hline Les.2409.1.S1_at & $\begin{array}{l}\text { dnaJ related } \\
\text { molecular chaperone }\end{array}$ & 2.30 & 0.050 & 1.57 & 0.537 \\
\hline LesAffx.43379.1.S1_at & dnaJ homologue 3 & 2.71 & 0.052 & 1.64 & 0.623 \\
\hline LesAffx.71535.1.S1_at & heat shock protein & 2.81 & 0.077 & 1.72 & 0.639 \\
\hline Les.641.1.S1_at & $\begin{array}{l}\text { dnaJ heat shock } \\
\text { protein }\end{array}$ & 3.01 & 0.067 & 1.95 & 0.746 \\
\hline LesAffx.66226.2.S1_at & $\begin{array}{l}\text { cold-regulated } \\
\text { plasma membrane } 1 \\
\text { protein }\end{array}$ & 3.28 & 0.044 & 1.97 & 0.180 \\
\hline
\end{tabular}


Table 4: Differentially regulated stress and defense response genes. (Continued)

\begin{tabular}{llcccc}
\hline Les.5158.1.S1_at & $\begin{array}{l}\text { dehydration response } \\
\text { element B1A }\end{array}$ & $\mathbf{3 . 3 6}$ & $\mathbf{0 . 0 9 2}$ & 1.99 & 0.218 \\
\hline LesAffx.59336.1.S1_at & $\begin{array}{l}\text { response to } \\
\text { desiccation 26-like } \\
\text { transcription factor }\end{array}$ & $\mathbf{3 . 5 9}$ & $\mathbf{0 . 0 8 2}$ & 2.25 & 0.231 \\
\hline
\end{tabular}

Probe Set ID; Affymetrix identifier for each microarray probeset. Putative Annotation; functional annotation based on tomato protein function or function of Arabidopsis orthologues identified with BLAST searches. Fold Change; linear fold changes (bold values significant at False Discovery Rate (FDR) adjusted P-value $<0.10)$.

\section{Conclusions}

Spatially discrete $\mathrm{NH}_{4}{ }^{+}$is quickly transformed in the soil and taken up by plants, and the tomato root transcriptome reflects levels of $\mathrm{N}$ availability and transformations of $\mathrm{N}$ that occur in the soil. The dynamic regulation of both $\mathrm{NH}_{4}{ }^{+}$and $\mathrm{NO}_{3}{ }^{-}$transporters in $\mathrm{N}$-patch roots demonstrates that roots are able to simultaneously sense and respond to both forms of inorganic $\mathrm{N}$, in ways that are likely to increase root competition with microbial immobilization, nitrification, and denitrification, and conserve $\mathrm{N}$ within cropping systems. The arbuscular mycorrhizal symbiosis may further increase the effective recovery of other nutrients such as $\mathrm{P}$ in an $\mathrm{N}$ patch. The strong and diverse transcriptional response to the soil $\mathrm{N}$ patch illustrates the utility of applying transcriptomic studies to plants growing in realistic soil environments and the key genes co-regulated under high and low $\mathrm{N}$ conditions in this study may serve as molecular tools for monitoring plant $\mathrm{N}$ status in agricultural sites for finer tuning of fertilizer application, soil microbial $\mathrm{N}$ processes, and ultimately, to develop more efficient agriculture methods.

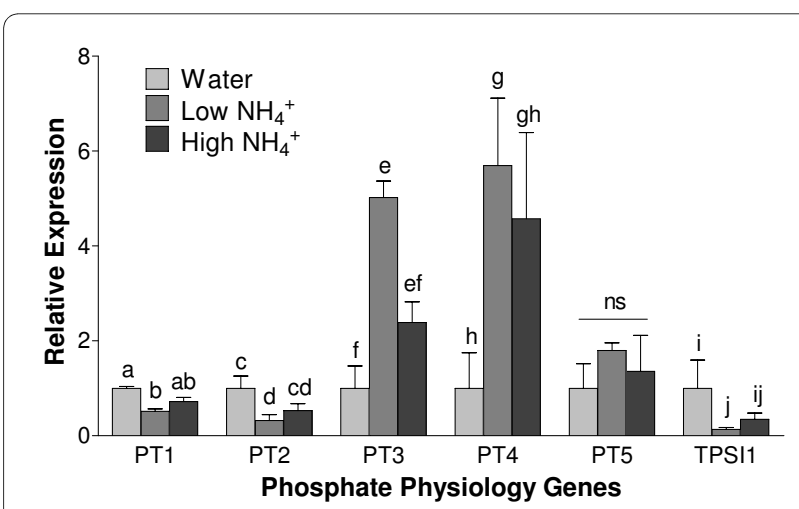

Figure 4 qRT-PCR analysis of phosphate physiology genes. Expression levels of the tomato phosphate transporters and phosphate starvation response gene TPSII in patch roots harvested $53 \mathrm{hrs}$ after high ( $65 \mu \mathrm{g} \mathrm{NH}_{4}^{+-} \mathrm{N} \mathrm{g}^{-1}$ soil), low $\left(6.5 \mu \mathrm{g} \mathrm{NH}_{4}^{+-} \mathrm{N} \mathrm{g}^{-1}\right.$ soil), or water control treatments. Relative quantity was calculated using the $\triangle \triangle C T$ method with actin (LeACT) as the reference control, and the water control group normalized to 1 . For a given gene, means followed by different letters are significantly different from one another at $P<0.05$ (one way ANOVA).

\section{Methods}

\section{Soil and plant material}

Seeds of Solanum lycopersicum L. Cv. 76R [60] were surface sterilized, germinated with mist irrigation and then watered with one-tenth strength Long Ashton's solution containing $\mathrm{N}$ as $\left(\mathrm{NH}_{4}\right)_{2} \mathrm{SO}_{4}(4 \mathrm{mM})$ and $\mathrm{NaNO}_{3}(8 \mathrm{mM})$. Plants were maintained under day/night length of $16 / 8 \mathrm{hr}$ in UC Davis glasshouses. Seven week old seedlings were transplanted into $12-\mathrm{L}$ pots containing buried rings with field-collected soil (Zamora loam, a fine silty, mixed thermic, Mollic Haploxeralfs) collected on an organically managed farm (Jim and Deborah Durst Farming in Esparto, Yolo County, California) [8]. The buried soil root in-growth cores (rings) were $7.3 \mathrm{~cm}$ in diameter and 4.2 $\mathrm{cm}$ tall (total volume $176 \mathrm{~cm}^{3}$ ) and were filled with $210 \mathrm{~g}$ of field soil to a final bulk density equal to that of the surrounding soil $\left(1.2 \mathrm{~g} \mathrm{~cm}^{-3}\right)$. The broad ends of the ring were covered with $1 \mathrm{~mm}$ plastic mesh to easily allow roots to grow up and down into the ring. The soil was passed through a $1 \mathrm{~cm}$ sieve before packing into pots at a bulk density of $1.2 \mathrm{~g} \mathrm{~cm}^{-3}$. Extractable inorganic $\mathrm{N}$ (mean \pm standard error) was $0.20 \pm 0.02 \mu \mathrm{g} \mathrm{NH}_{4}{ }^{+} \mathrm{N} \mathrm{g}^{-1}$ dry soil and $9.7 \pm 1.09 \mu \mathrm{g} \mathrm{NO}_{3}-\mathrm{N} \mathrm{g}^{-1}$ dry soil at the time the rings were prepared. An application of one tenth strength Long Ashton's solution was applied two weeks after transplanting. Soil moisture was maintained gravimetrically at $19 \%$ before and after treatment injection by weighing the pots daily, and watering to compensate for evapotranspiration water loss.

\section{Experimental design}

We applied the nutrient treatments five weeks after transplantation by injecting 9 aliquots of $2 \mathrm{~mL}$ solution inside the buried ring using a template placed on the soil surface to assure an even distribution of nutrients and minimal loss of the solution. We added $6.5 \mu \mathrm{g}$ and $65 \mu \mathrm{g}{ }^{15} \mathrm{NH}_{4}{ }^{+}-\mathrm{N}$ (99 atom percent) $\mathrm{g}^{-1}$ dry soil in the ring for the low and high $\mathrm{NH}_{4}{ }^{+}$treatments, respectively $\left(1.35 \mathrm{mg}{ }^{15} \mathrm{NH}_{4}{ }^{+}-\mathrm{N}\right.$ per ring and $13.5 \mathrm{mg}{ }^{15} \mathrm{NH}_{4}{ }^{+} \mathrm{N}$ per ring, respectively). Water was used as a control. Each treatment consisted of three biological replicates, and plants were destructively harvested at 5, 29, 53, and $96 \mathrm{hrs}$ after ${ }^{15} \mathrm{NH}_{4}{ }^{+}-\mathrm{N}$ addition, 
for a total number of 36 plants in an unreplicated block design. The transcriptome analyses were performed on roots harvested at $53 \mathrm{hrs}$ post-treatment.

\section{Harvest and sample analysis}

At harvest, shoots were severed at the soil surface, dried at $60^{\circ} \mathrm{C}$, weighed, and ground to a fine powder for isotope analyses. Immediately following the harvest of the aboveground biomass, the root in-growth rings were carefully exposed, and the roots growing into and out of the ring were severed. Patch roots for transcriptome analysis were rinsed and immediately frozen in liquid nitrogen. A homogenous sub-sample of the patch soil and the surrounding pot soil was immediately removed for gravimetric water content and soil inorganic $\mathrm{N}$ concentrations. Soil $\mathrm{NH}_{4}{ }^{+}$and $\mathrm{NO}_{3}{ }^{-}$were analyzed after $\mathrm{KCl}$ extractions and colorimetric determination using modifications of Miranda et al., [61] and Foster et al., [62] respectively. A small subsample of ring roots was scored for arbuscular mycorrhizal fungi at $200 \times$ [63]. The remaining patch roots were washed by wet sieving, dried at $60^{\circ} \mathrm{C}$, weighed, and ground to a fine powder for isotope analyses. All dried plant material was analyzed for $\delta^{15} \mathrm{~N}$ on a PDZ Europa ANCA-GSL elemental analyzer and a PDZ Europa 20-20 isotope ratio mass spectrometer (Sercon Ltd., Cheshire, UK) at the UC Davis Stable Isotope Facility, USA. Background ${ }^{15} \mathrm{~N}$ was calculated as the average atom percent ${ }^{15} \mathrm{~N}$ in the water samples (mean atom percent ${ }^{15} \mathrm{~N} \pm$ SD in shoots: $0.369 \% \pm 0.0003$ ). Leaf total $\mathrm{P}$ was analyzed by microwave digestion with nitric acid/ hydrogen peroxide [64] followed by atomic absorption spectrometry and inductively coupled plasma atomic emission spectrometry at the UC Davis Division of Agriculture and Natural Resource Laboratory.

\section{Soil analysis}

Soil nutrient and plant isotope data were analyzed with a two-way analysis of variance (ANOVA) with harvest time, nutrient addition, and block as fixed main effects. All two-way interactions were tested. The three way interaction was not tested because of insufficient degrees of freedom. Data was checked to assure that the ANOVA assumptions were met and was transformed as necessary. Tukey-Kramer Honestly Significant Difference test was used to determine differences between means at $\mathrm{P}<0.05$. All data were analyzed using R ( $\mathrm{R}$ Core Development Team 2007).

\section{RNA isolation}

Root RNA samples were extracted using the RNeasy Plant Mini Kit (Qiagen Sciences, Germantown, MD, USA) following the manufactures guidelines plus a third wash step before elution. RNA concentrations and quality were assessed using the Agilent Nanodrop and the RNA
6000 Nano Assay (Bioanalyzer 2100, Agilent, Santa Clara CA). RNA samples had RNA integrity numbers (RIN) of at least 7.0. DNase digestion was performed on 20 ug total RNA using RQ1 RNase-free DNase (Promega, Madison WI). These RNA were used for both microarray analysis and cDNA synthesis for qRT-PCR analysis.

\section{Microarray analysis}

Transcriptome profiling of each 53h-post injection RNA sample was performed using the Tomato Genome Array Chip (Affymetrix, Santa Clara, CA, USA). RNA samples were prepared for microarray analysis using the MessageAmp Premier RNA Amplification Kit (Ambion, Foster City CA) with $200 \mathrm{ng}$ total RNA as input. Fragmented cRNA samples were then sent to the University of Missouri's DNA Core Facility for Array hybridization and scanning. Each array's CEL file was summarized in Affymetrix Expression Console software using the MAS5 algorithm. The signal intensities were log transformed, and quality control analysis performed. This array data has been made available on the Gene Expression Omnibus (GEO; http://www.ncbi.nlm.nih.gov/projects/geo/) accession \#GSE21020. The data were filtered to remove probesets whose log signal intensity was below 4.605 in all 9 arrays. For each probeset, which represents the combined expression data from all relevant probe pairs on the chip, the generalized linear model $Y_{i j}=\mu+T_{i}+\varepsilon_{i j}$ was fit. In each ANOVA, $Y_{\mathrm{ij}}$ is the log normalized transcript level for the $i^{\text {th }}$ treatment and the $j^{\text {th }}$ replicate, $\mu$ is the overall mean expression for the probeset and Ti represents the $i^{\text {th }}$ treatment (water, low nutrient, and high nutrient). The null hypothesis $t_{1}=t_{0}$ (i.e., mean expression not different between a pair of treatments) was tested using an F-test. We examined the model for conformation to the assumption of normality of the residuals testing the null hypothesis that the residuals for each gene were normally distributed using the Shapiro-Wilk Test. All analyses were performed in JMP Genomics 3.0 (SAS Institute, Cary $\mathrm{NC}$ ). An FDR level of $10 \%$ was used for declaring findings significant, and a stringent rate of $5 \%$ was also examined $[65,66]$. ANOVA analysis of all differentially expressed genes can be found in Additional file 1. The list of statistically significant transcripts was initially annotated using the Affymetrix NetAffyx annotation file to match a representative Genbank public ID and Unigene to each probeset. The functional annotations of the Unigenes were grouped into functional categories as described in Bevan et al. [67]. In cases where the tomato gene did not have a matching Unigene or had not been functionally annotated, the tomato sequence was used to identify Arabidopsis orthologues by WU-BLAST searches at TAIR [68]. To test for enrichment of specific functional categories between the high vs water and low vs. water pairwise comparisons, Fisher's exact test was performed using 
GraphPad Prism 5.0, San Diego CA). Within specific categories, binomial distribution probability tests were performed to test for enrichment in the up/down regulation patterns of functionally related genes (expectation $=0.5$ ).

\section{Quantitative real-time RT-PCR}

cDNA was synthesized from 1.5 ug DNase-treated total RNA using the Superscript III kit (Invitrogen Carlesbad CA). Gene-specific primer sets were designed using IDT's primerquest software program (Additional file 3), and their sequence uniqueness confirmed with a nucleotide BLAST search against the tomato genome database. Primer pairs were tested for specificity and efficiency with serial dilution reactions and dissociation curve analysis post-amplification. Real-time PCR reactions were run on the Stratagene MX3000 PCR machine using Sybr Green chemistry (Invitrogen Platinum Sybr Green II master mix, $400 \mathrm{nM}$ primer concentration, ROX reference dye, and 1:150 diluted cDNA). Multiple reference control genes were tested against all samples to identify control genes whose expression was not affected by the $\mathrm{NH}_{4}{ }^{+}$treatments. LeACT and LeUBI were similarly expressed across the samples while LeTubulin was differentially expressed. LeACT was subsequently used as the reference control gene, and the relative expression of the various target genes was analyzed according to the $\Delta \Delta C T$ method [69]. Standard error was computed from the average of the $\Delta C T$ values for each biological sample [70].

\section{Additional material}

Additional file $\mathbf{1}$ Microarray analysis of differentially expressed genes across all treatments including the Affymetrix probeset ID, Genbank public ID, linear fold changes, FDR P-values, gene annotation information, and probeset redundancy information.

Additional file 2 Genes similarly regulated by high $\mathrm{NH}_{4}{ }^{+}$and low $\mathrm{NH}_{4}{ }^{+}$ treatments compared to the water control.

Additional file $\mathbf{3}$ Primer sequences for genes assayed with qRT-PCR.

\section{Authors' contributions}

DRR carried out the microarray and molecular genetic studies, participated in the statistical analyses, and drafted the manuscript. FB-M and NTH participated in the greenhouse experiments and nutrient analyses, and helped write the manuscript. LEJ and DPS designed and coordinated the study, participated in the greenhouse experiments and data analyses, and helped write the manuscript. All authors read and approved the final manuscript.

\section{Acknowledgements}

We thank Lauren McIntyre for her insights and contributions to the microarray analysis, Julie Chou, Kimberly Jacobs, Julien Linares, Walter Lopez, and Annie Young-Matthews for their help in the execution of the experiment and subsequent sample processing, the University of Missouri DNA Core Facility for hybridization and scanning of the Affymetrix GeneChips, and the National Science Foundation for funding support (\#0723775 to DPS and LEJ).

\section{Author Details}

1Donald Danforth Plant Science Center, 975 N Warson Rd., St. Louis MO 63132 USA and ${ }^{2}$ Department of Land, Air, and Water Resources, University of California, 1 Shields Avenue, Davis CA 95616 USA
Received: 3 February 2010 Accepted: 27 April 2010

Published: 27 April 2010

\section{References}

1. Burger M, Jackson LE: Microbial immobilization of ammonium and nitrate in relation to ammonification and nitrification rates in organic and conventional cropping systems. Soil Biology and Biochemistry 2003, 35:29-36.

2. Booth MS, Stark JM, Rastetter E: Controls on nitrogen cycling in terrestrial ecosystems: A synthetic analysis of literature data. Ecological Monographs 2005, 75:139-157

3. Schimel JP, Bennett J: Nitrogen mineralization: Challenges of a changing paradigm. Ecology 2004, 85:591-602.

4. Hodge A: The plastic plant: root responses to heterogeneous supplies of nutrients. New Phytologist 2004, 162:9-24

5. Granato TC, Raper CD: Proliferation of maize (Zea mays $\mathrm{L}$ ) roots in response to localized supply of nitrate. Journal of Experimental Botany 1989, 40:263-75.

6. Garnett T, Conn V, Kaiser BN: Root based approaches to improving nitrogen use efficiency in plants. Plant, Cell and Environment 2009, 32:1272-1283.

7. Tibbett M: Roots foraging and the exploration of soil nutrient patches: the role of the mycorrhizal symbiosis. Functional Ecology 2000 14:397-99.

8. Cavagnaro TR, Jackson LE, Six J, Ferris H, Goyal S, Asami D, Scow KM: Arbuscular mycorrhizas, microbial communities, nutrient availability, and soil aggregates in organic tomato production. Plant and Soil 2006 282:209-225.

9. Lea PJ, Azevedo RA: Nitrogen use efficiency. 1. Uptake of nitrogen from the soil. Annals of Applied Biology 2006, 149:243-247.

10. Lea PJ, Azevedo RA: Nitrogen use efficiency. 2. Amino acid metabolism. Annals of Applied Biology 2007, 151:269-275.

11. Glass ADM, Britto DT, Kaiser BN, Kinghorn JR, Kronzucker HJ, Kumar A, Okamoto M, Rawat S, Siddiqi MY, Unkles SE, et al: The regulation of nitrate and ammonium transport systems in plants. Journal of Experimental Botany 2002, 53:855-864.

12. Loqué $\mathrm{D}$, von Wirén $\mathrm{N}$ : Regulatory levels for the transport of ammonium in plant roots. Journal of Experimental Botany 2004, 55:1293-1305.

13. Glass ADM: Nitrate uptake by plant roots. Botany $2009,87: 659-667$.

14. Ludewig U, Neuhäuser B, Dynowski M: Molecular mechanisms of ammonium transport and accumulation in plants. FEBS Letters 2007 581:2301-2308

15. Howitt SM, Udvardi MK: Structure, function and regulation of ammonium transporters in plants. Biochimica Et Biophysica Acta 2000, 1465:152-170.

16. Miller AJ, Cramer MD: Root nitrogen acquisition and assimilation. Plant and Soil 2005, 274:1-36.

17. Tsay YF, Chiu CC, Tsai CB, Ho CH, Hsu PK: Nitrate transporters and peptide transporters. FEBS Letters 2007, 581:2290-2300.

18. Loqué $D$, von Wirén $N$ : Regulatory levels for the transport of ammonium in plant roots. Journal of Experimental Botany 2004, 55:1293-1305.

19. Wang YH, Garvin DF, Kochian LV: Nitrate-induced genes in tomato roots. Array analysis reveals novel genes that may play a role in nitrogen nutrition. Plant Physiology 2001, 127:345-359.

20. Scheible WR, Morcuende R, Czechowski T, Fritz C, Osuna D, Palacios-Rojas N, Schindelasch D, Thimm O, Udvardi MK, Stitt M: Genome-wide reprogramming of primary and secondary metabolism, protein synthesis, cellular growth processes, and the regulatory infrastructure of Arabidopsis in response to nitrogen. Plant Physiology 2004, 136:2483-2499.

21. Wang $Y H$, Okamota $M$, Xing $X$, Crawford NM: Microarray analysis of the nitrate response in Arabidopsis roots and shoots reveals over 1000 rapidly responding genes and new linkages to glucose, trehalose-6phosphate, iron, and sulfate metabolism. Plant Physiology 2003, 132:556-567.

22. Lopes MS, Araus JL: Comparative genomic and physiological analysis of nutrient response to $\mathrm{NH}_{4}{ }^{+}, \mathrm{NH}_{4}{ }^{+}: \mathrm{NO}_{3}{ }^{-}$and $\mathrm{NO}_{3}{ }^{-}$in barley seedlings. Physiologia Plantarum 2008, 134:134-150. 
23. Nagy R, Karandashov V, Chague V, Kalinkevich K, Tamasloukht M, Xu G, Jakobsen I, Levy AA, Amrhein N, Bucher M: The characterization of novel mycorrhiza-specific phosphate transporters from Lycopersicon esculentum and Solanum tuberosum uncovers functional redundancy in symbiotic phosphate transport in solanaceous species. Plant Journal 2005, 42:236-250.

24. Xu GH, Chague V, Melamed-Bessudo C, Kapulnik Y, Jain A, Raghothama KG, Levy AA, Silber A: Functional characterization of LePT4: A phosphate transporter in tomato with mycorrhiza-enhanced expression. Journal of Experimental Botany 2007, 58:2491-2501.

25. Nagy R, Drissner D, Amrhein N, Jakobsen I, Bucher M: Mycorrhizal phosphate uptake pathway in tomato is phosphorus-repressible and transcriptionally regulated. New Phytologist 2009, 181:950-959.

26. Javot H, Pumplin N, Harrison MJ: Phosphate in the arbuscular mycorrhizal symbiosis: transport properties and regulator roles. Plant Cell and Environment 2007, 30:310-322.

27. Burger M, Jackson LE, Lundquist EJ, Louie DT, Miller RL, Rolston DE, Scow KM: Microbial responses and nitrous oxide emissions during wetting and drying of organically and conventionally managed soil under tomatoes. Biology and Fertility of Soils 2005, 42:109-118.

28. Fageria NK, Baligar VC: Enhancing nitrogen use efficiency in crop plants. Advances in Agronomy 2005, 88:97-185

29. Hutchings MJ, de Kroon H: Foraging in plants: The role of morphological plasticity in resource acquisition. Advances in Ecological Research 1994, 25:159-238.

30. Hodge A, Robinson D, Griffiths BS, Fitter AH: Why plants bother: Root proliferation results in increased nitrogen capture from an organic patch when two grasses compete. Plant Cell and Environment 1999, 22:811-820

31. Richardson AE, Barea JM, McNeill AM, Prignet-Combaret C: Acquisition of phosphorus and nitrogen in the rhizosphere and plant growth promotion by microorganisms. Plant Soil 2009, 321:305-339.

32. Jovanovic M, Lefebvre V, Laporte $P$, Gonzalez-Rizzo S, Lelandais-Brière C, Frugier F, Hartmann C, Crespi M: How the environment regulates root architecture in dicots. Advances in Botanical Research 2007, 46:35-74.

33. Vidal EA, Gutiérrez RA: A systems view of nitrogen nutrient and metabolite responses in Arabidopsis. Current Opinion in Plant Biology 2008, 11:521-529.

34. Meshi T, Taoka Kl, Iwabuchi M: Regulation of histone gene expression during the cell cycle. Plant Molecular Biology 2000, 43:643-657.

35. Shaw P, Dolan L: Chromatin and Arabidopsis root development. Seminars in Cell and Developmental Biology 2008, 19:580-585.

36. Menges M, Hennig L, Gruissem W, Murray JAH: Cell cycle-regulated gene expression in Arabidopsis. Journal of Biological Chemistry 2002, 277:41987-42002.

37. Inze D, De Veylder L: Cell cycle regulation in plant development. Annual Review of Genetics 2006, 40:77-105.

38. Zhong R, Ye ZH: Regulation of cell wall biosynthesis. Current Opinion in Plant Biology 2007, 10:564-572.

39. Liu J, Han L, Chen F, Bao J, Zhang F, Mi G: Microarray analysis reveals early responsive genes possibly involved in localized nitrate stimulation of lateral root development in maize (Zea mays L.). Plant Science 2008, 175:272-282.

40. Schachtman DP, Shin R: Nutrient sensing and signaling: NPKS. Annual Review of Plant Biology 2007, 58:47-69.

41. Bi YM, Wang RL, Zhu T, Rothstein SJ: Global transcription profiling reveals differential responses to chronic nitrogen stress and putative nitrogen regulatory components in Arabidopsis. BMC Genomics 2007, 8:281

42. Lian X, Wang S, Zhang J, Feng Q, Zhang L, Fan D, Li X, Yuan D, Han B, Zhang Q: Expression profiles of 10,422 genes at early stage of low nitrogen stress in rice assayed using a cDNA microarray. Plant Molecular Biology 2006, 60:617-631.

43. Lauter FR, Ninnemann O, Bucher $M$, Riesmeier JW, Frommer WB Preferential expression of an ammonium transporter and of two putative nitrate transporters in root hairs of tomato. PNAS 1996, 93:8139-8144

44. von Wirén N, Lauter FR, Ninnemann O, Gillissen B, Walch-Liu P, Engels C, Jost W, Frommer WB: Differential regulation of three functional ammonium transporter genes by nitrogen in root hairs and by light in leaves of tomato. The Plant Journal 2000, 21:167-175.
45. Loqué D, Yuan L, Kojima S, Gojon A, Wirth J, Gazzarrini S, Ishiyama K, Takahashi $\mathrm{H}$, von Wirén N: Additive contribution of AMT1;1 and AMT1;3 to high-affinity ammonium uptake across the plasma membrane of nitrogen-deficient Arabidopsis roots. Plant Journal 2006, 48:522-534

46. Forde BG, Walch-Liu P: Nitrate and glutamate as environmental cues for behavioural responses in plant roots. Plant, Cell and Environment 2009 32:682-693.

47. Zhang H, Forde BG: An Arabidopsis MADS box gene that controls nutrient-induced changes in root architecture. Science 1998 279:407-409.

48. Gan Y, Filleur S, Rahman A, Gotensparre S, Forde BG: Nutritional regulation of ANR1 and other root-expressed MADS-box genes in Arabidopsis thaliana. Planta 2005, 22:730-742

49. Maynard DN, Hochmuth GJ: Handbook for Vegetable Growers New York: John Wiley and Sons, Inc; 1997.

50. Zhu GH, Zhuang CX, Wang YQ, Jiang LR, Peng XX: Differential expression of rice genes under different nitrogen forms and their relationship with sulfur metabolism. Journal of Integrative Plant Biology 2006, 48:1177-1184

51. Armengaud $P$, Breitling $R$, Amtmann A: The potassium-dependant transcriptome of Arabidopsis reveals a prominent role of jasmonic acid in nutrient signaling. Plant Physiology 2004, 136:2556-2576.

52. Armengaud P, Sulpice R, Miller AJ, Stitt M, Amtmann A, Gibon Y: Multilevel analysis of primary metabolism provides new insights into the role of potassium nutrition for glycolysis and nitrogen assimilation in Arabidopsis roots. Plant Physiology 2009, 150:772-785

53. Gniazdowska A, Krawczak A, Mikulska M, Rychter AM: Low phosphate nutrition alters bean plants' ability to assimilate and translocate nitrate. Journal of Plant Nutrition 1999, 22:551-563.

54. de Groot CC, Marcelis LFM, va den Boogaard R, Kaiser WM, Lambers H: Interaction of nitrogen and phosphorus nutrition in determining growth. Plant and Soil 2003, 248:257-268.

55. Olsson PA, Burleigh SH, va Aarle IM: The influence of external nitrogen on carbon allocation to Glomus intraradicies in monoexinc arbuscular mycorrhiza. New Phytologist 2005, 168:677-686.

56. Liu C, Muchhal US, Uthappa M, Kononowicz AK, Raghothama KG: Tomato phosphate transporter genes are differentially regulated in plant tissues by phosphorus. Plant Physiology 1998, 116:91-99.

57. Poulsen KH, Nagy R, Gao LL, Smith SE, Bucher M, Smith FA, Jakobsen I: Physiological and molecular evidence for Pi uptake via the symbiotic pathway in a reduced mycorrhizal colonization mutant in tomato associated with a compatible fungus. New Phytologist 2005, 168:445-454.

58. Nagy R, Vasconcelos MJV, Zhao S, McElver J, Bruce W, Amrhein N, Raghothama KG, Bucher M: Differential regulation of five Pht 1 phosphate transporters from maize (Zea mays L.). Plant Biology 2006, 8:186-197.

59. Liu C, Muchhal US, Raghothama KG: Differential expression of TPS11, a phosphate staration-induced gene in tomato. Plant Molecular Biology 1997, 33:867-874

60. Barker SJ, Stummer B, Gao L, Dispain I, O'Connor PJ, Smith SE: A mutant in Lycopersicon esculentum Mill. with highly reduced VA mycorrhizal colonization: Isolation and preliminary characterisation. Plant Journal 1998, 15:791-797.

61. Miranda KM, Espey MG, Wink DA: A rapid, simple spectrophotometric method for simultaneous detection of nitrate and nitrite. Nitric OxideBiology and Chemistry 2001, 5:62-71.

62. Foster JC: Soil nitrogen. In Methods in applied soil microbiology and biochemistry San Diego: Academic Press; 1995:79-87.

63. McGonigle TP, Miller MH, Evans DG, Fairchid GL, Swan JA: A new method which gives an objective measure of colonization of roots by vesiculararbuscular mycorrhizal fungi. New Phytologist 1990, 115:495-501.

64. Sah RN, Miller RO: Spontaneous reaction for acid dissolution of biological tissues in closed vessels. Analytical Chemistry 1992. 64:230-233.

65. Benjamini $Y$, Hochberg $Y$ : Controlling the false discovery rate: a practical and powerful approach to multiple testing. Journal of the Royal Statistical Society Series B 1995, 57:289-300.

66. Verhoeven KJF, Simonsen KL, Mclntyre LM: Implementing false discovery rate control: Increasing your power. Oikos 2005, 108:643-647.

67. Bevan M, Bancroft I, Bent E, Love K, Goodman H, Dean C, Bergkamp R, Dirske W, Van Staveren M, Stiekema W, et al:: Analysis of $1.9 \mathrm{Mb}$ of 
contiguous sequence from chromosome 4 of Arabidopsis thaliana. Nature 1998, 391:485-488.

68. Altschul SF, Gish W, Miller W, Myers EW, Lipman DJ: Basic local alignment search tool. Journal of Molecular Biology 1990, 215:403-410.

69. Pfaffl MW: A new mathematical model for relative quantification in realtime RT-PCR. Nucleic Acids Research 2001, 29:.

70. Livak KJ, Schmittgen TD: Analysis of relative gene expression data using real-time quantitative PCR and the 2- $\Delta \Delta C T$ method. Methods 2001 , 25:402-408

doi: $10.1186 / 1471-2229-10-75$

Cite this article as: Ruzicka et al., Tomato root transcriptome response to a nitrogen-enriched soil patch BMC Plant Biology 2010, 10:75

Submit your next manuscript to BioMed Central and take full advantage of:

- Convenient online submission

- Thorough peer review

- No space constraints or color figure charges

- Immediate publication on acceptance

- Inclusion in PubMed, CAS, Scopus and Google Scholar

- Research which is freely available for redistribution

Submit your manuscript at www.biomedcentral.com/submit
() BioMed Central 